\title{
COGNITIVE EMOTION AND THE LAW
}

\author{
HAROLD ANTHONY LLOYD*
}

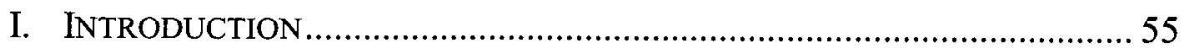

II. MODERN NEUROSCIENCE, PREFERENCE, AND TIIE

NECESSARY ROLE OF PATHOS IN LOGOS ............................................. 58

A. Emotion and Reason as "Co-Dependent" in the

Brain.

B. Emotion and Reason as "Co-Dependent" in

Practice....

C. "Co-Dependency" and Modern Notions of

Rational Choice

III. FEELING AND BEYOND: THE BROAD RANGE OF PATHOS

AND AFFECTIVE EXPERIENCE

A. Feeling as Frequent Part but Not Whole of Affective Experience....

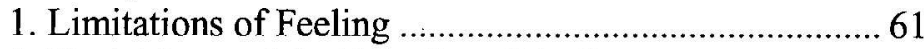

2. Huck Finn and the Benefits of Feeling ........................ 62

B. The Affective as Intentional and Thus Potentially Rational

C. The Affective as Intentional and Thus Creative

D. The Affective As Intentional With a "Personal Stake"

1. "Personal Stake" As Differentiating Pathos from Logos

2. "Pensive" vs. "Emotional" Malice ............................... 67

3. A Distinction with a Meaningful Difference ................ 67

IV. DistinguishING BETWEEN AFFECTIVE STATES BASED ON

TYPE OF INTENTIONALITY, OCCURRENCE STATUS, AND

DURATION

\footnotetext{
- (c) 2016 Associate Professor Wake Forest University School of Law. I would like to thank my research assistants Ashley Barton and Ryan Holt for their very valuable help and assistance. I would also like to thank Marissa Stanziani and Adam Coffey for their careful review and useful thoughts, the staff of the LAW \& PSYCHOLOGY REVIEW for their excellent work, and the late Robert C. Solomon for his invaluable influence and insights. I wish I could have known Professor Solomon in person rather than only through his writings. Any errors or other shortcomings are of course my own.
} 
A. Emotion: Specific Intent, Occurrence, and "Short" Duration

B. Sentiment: Specific Intent, Disposition, and

"Longer" Duration.

C. Mood: General Intent, Occurrence, and "Short"

Duration

D. Trait: General Intent, Disposition, and "Longer"

Duration...

V. FOCUSING FURTHER ON EMOTION: ELEMENTS AND

OPTIONS

A. Levels of Describing Emotion ................................................... 71

B. Necessary Elements of Emotion ................................................. 71

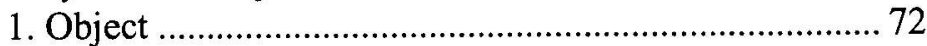

2. Appraisal: Mechanics, Concepts, Narratives, and Lawyer Checklists ............................... 73

3. Desire or Motivation.................................................... 75

4. Distinctive "Core Themes"........................................... 75

a. Hatred and Employment

Discrimination ................................................ 75

b. Disgust and Employment

Discrimination ............................................. 77

c. Why Lawyers Should Parse

Emotions Carefully........................................ 78

C. Optional Accompaniments of Emotion .................................... 79

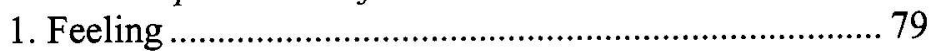

2. Action Tendency vs. Desire......................................... 80

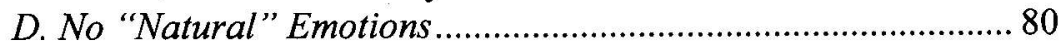

VI. EMOTION AND THE LAW: THREE ADDITIONAL SPECIFIC

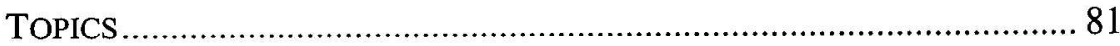

A. Emotion as Expression and the First Amendment .................... 82

1. Signifiers and the Mechanics of Expressing

Emotion

2. Emotion and Reasons for Protecting

Freedom of Expression ........................................... 84

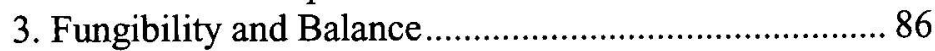

a. Emotion, Expression, and Cohen on Signifiers......................................................... 86

b. Snyder, "Truth Value," and

Emotions......................................................... 87

c. Unique Indexical Issues ................................... 88

4. The Need for Future Work ........................................... 90

B. Emotion as Elements and Exceptions in Criminal

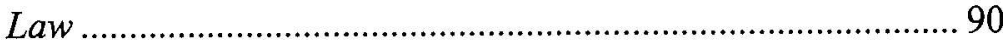

C. Emotion and Lawyer Mental Health ......................................... 92 
1. Lawyers and Guilt 92

2. Lawyers and Remorse ............................................... 95

3. Lawyers and Regret .................................................. 96

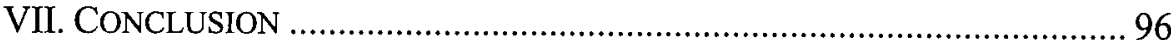

APPENDIX: RUBRICS OF SEVERAL SPECIFIC EMOTIONS .......................... 99

\section{INTRODUCTION}

Many people wrongly believe that emotion or other affective experience should play little or no role in legal or other "pure" reasoning. ${ }^{1}$ Langdell's odd notion that law is a certain science of appellate cases no doubt fuels such error. ${ }^{2}$ If law is lab work, law can easily be seen as doubly removed from emotion. To the extent such lab work involves induction, should the rules of induction not suffice $?^{3}$ To the extent such lab work involves deduction, should the rules of deduction not suffice? ${ }^{4}$ If so, where can there be any room for emotion?

As we shall see, things are not so simple. Even if law were Langdell's certain science of appellate cases (which it is not ${ }^{5}$ ), emotion could not be torn from doing such science. First, life itself shows us that it is "sometimes irrational to be detached and impersonal" when we make decisions since "emotions are sometimes more insightful than the more detached and

1. See, e.g., Caroline Maughan, Why Study Emotion?, in AfFect AND LeGal EduCATION: EMotion IN LEARNING AND TEACHING THE LAw 11, 18 (Paul Maharg \& Caroline Maughan, eds., 2011) [hereinafter Maughan, Why Study Emotion?] ("Affect has no place in the academy. Dominated by Cartesian dualism, universities traditionally regarded themselves as centres of pure rationality, their purpose being the objective and dispassionate search for truth.")

2. See Harold Anthony Lloyd, Exercising Common Sense, Exorcising Langdell: The Inseparability of Legal Theory, Practice, and the Humanities, 49 WAKE FOREST L. REV. 1213, 1228 (2014) [hereinafter Lloyd, Exercising Common Sense]; Harold Anthony Lloyd, Raising the Bar, Razing Langdell, 51 WAKE FOREST L. REV. 231, 231 (2016) [hereinafter Lloyd, Razing Langdell]; see also Alan M. Lerner, From Socrates to Damascio, from Langdell to Kandel: The Role of Emotion in Modern Legal Education, in AFFECT AND LEgAL EDUCATION: EMOTION IN LEARNING AND TEACHING THE LAW, supra note 1, at 151 (noting Langdell saw law as a science whose "raw evidence" allows one to "reason one's way to the 'right' answers" "if one carefully and objectively analysed [sic] the raw evidence in its original state" and that such "raw evidence" was "primarily the decisions of appellate courts in the Anglo-American common law system").

3. See Richard A. Lanham, A Handlist of Rhetorical Terms 90 (2d ed. 2012) (defining inductive proof as "argument from the particular to the general; scientific reasoning").

4. See Stephen F. Barker, The Elements of Logic 317 (2d ed. 1974) (defining deduction as "[i]nference in which the conclusion follows necessarily from the premises").

5. See Lloyd, Razing Langdell, supra note 2, at 232-33; see also Susan A. Bandes, Introduction to THE PASSIONS OF LAW 1, 6 (Susan A. Bandes, ed. 1999) (noting the "law's insistence on neutral, emotionless judging" and the "law's devotion to the myth of an emotionless, cognition-driven legal system"). 
impersonal deliberations of reason." Second, upon a careful analysis, we will find that logos and pathos are intertwined, that there is not only logos in pathos but pathos in logos as well. ${ }^{7}$ As we shall see, both halves of this antimetabole belie Langdell, and I wish to fix some of the emotional damage Langdell and fellow formalists have done to the law. ${ }^{8}$

In doing this, I also want to help change what Susan A. Bandes calls "law's well-known insularity and unwillingness to learn from other disciplines." I agree with her that " $[\mathrm{t}]$ he development of law . . . has been harmed and stunted by the failure to heed the lessons learned in every discipline that has studied emotions." 10 With this article, I hope to do my little part to help remedy this unfortunate mindset.

I will therefore first step outside the law and very briefly survey modern neuroscience of emotion as well as the necessary "co-dependence" of reason and emotion in practicc. I will then turn to emotion and affective experience itself. For purposes of this article, I will follow contemporary "loose" usage of "affective" as a "general term used more or less interchangeably with others, such as emotion, emotionality, feeling, mood, etc." I will therefore use terms such as "affect" and "affective experience" to include feeling, emotion, and mood as I define those terms in more detail in Sections III and IV below.

I will reject the notion that affective experience is mere feeling (though I will not discount the importance of feeling). I will also reject claims that affective experience is necessarily irrational or beyond our control. Instead, as we shall see, such experience is often intentional and quite rational and controllable. Given the importance of affective experience in reasoning, law, and the very wellbeing of lawyers, I will therefore explore in more detail the different types of affective experience including emotions.

6. See Cheshire Calhoun \& Robert C. Solomon, Introduction to WHAT IS AN EMOTION? Classic Readings in Philosophical Psychology 31 (Cheshire Calhoun \& Robert C. Solomon eds., 1st ed. 1984) [hereinafter Calhoun \& Solomon]; see also infra Section III regarding "feeling" and other "non-rational" elements of "reason."

7. By "pathos" I mean to include feeling, emotion, and mood as I define those terms in more detail in Sections III and IV below. By "logos" I mean to include not only logic but thought and language as well. See LANHAM, supra note 3, at 96.

8. See Harold Anthony Lloyd, Plane Meaning and Thought: Real-World Semantics and Fictions of Originalism, 24 S. CAL. INTERDISC. L.J., 657, 676-77 (2015).

9. Bandes, supra note 5, at 7 .

10. Id.

11. Affect, The Penguin Dictionary of Pyschology (4th ed. 2009) (italics omitted). 
After exploring law and affective experience at such "macro" levels, I will then consider three more specific examples of the interaction of law and emotion: (i) emotion, expression, and the First Amendment, (ii) emotion in legal elements and exceptions, and (iii) emotion and lawyer mental health. These further specific areas hardly exhaust the many "micro" areas meriting discussion.

Finally, to provide lawyers and legal scholars with a "one-source" overview of emotion and the law, I have included an Appendix addressing a number of particular emotions.

I also recognize that much of what I will say here runs counter to "common sense" models of emotion, which take as paradigms such things as children's irrational temper tantrums and teenagers' irrational passions for unsuitable dates. These paradigms can of course easily lead one to see emotion as "irrational and disruptive," and even as "hallmark[s] of the irrational and the disruptive." 12 Such paradigms can easily suggest that emotion is undesirable and that "[c]ontrolling one's emotion is ... like the caging and taming of a wild beast." 13 Using such paradigms, one can also easily believe that "emotions are primitive responses" which are "brutish" or mere "gut reactions," which we must control "lest they interfere with reason." 14 Under this view, "mature and civilized behavior becomes almost synonymous with 'taming' the emotions."15 Perhaps such paradigms, paired with a heavy dose of Langdell's lifeless formalism, ${ }^{16}$ have continued to give us the "conventional story" of the law-allowing emotion only a narrowly defined place in law. As Susan A. Bandes notes, the "conventional story" of emotion:

is assigned to the criminal courts. It is confined to thoselike witnesses, the accused, the public-without legal training. In this story, there is a finite list of law-related

12. See Robert C. Solomon, Emotions and Choice, in WHAT IS AN EMOTION? ClASSIC AND CONTEMPORARY READINGS 224, 224 (Cheshire Calhoun \& Robert C. Solomon eds., 2d ed. 2003) [hereinafter Solomon, Emotions and Choice]; see also Paul Maharg \& Caroline Maughan, Introduction to AFFECT AND LEGAL EDUCATION: EMOTION IN LEARNING AND TEACHING THE LAW, supra note 1, at 1 [hereinafter Maharg \& Maughan] ("[A]ffect itself is problematic because it is often seen as irrational, and antithetical to core Western ideals of rationality.").

13. See Solomon, Emotions and Choice, supra note 12, at 224.

14. JAMES R. AVERILl \& ELMA P. NUNLEY, VOYAGES OF THE HEART: LIVING AN EMOTIONALLY Creatrve Life xi (1992) [hercinaftcr AVERILL \& NUNLEY].

15. Id.

16. See Lloyd, Razing Langdell, supra note 2, at 231; Lloyd, Exercising Common Sense, supra note 2 , at 1213 . 
emotions-anger, compassion, mercy, vengeance, hatred-and each emotion has a proper role and a fixed definition. And it is portrayed as crucially important to narrowly delineate that finite list and those proper roles so that emotion doesn't encroach on the true preserve of law: which is reason. ${ }^{17}$

It is this "conventional story" that I wish to help rewrite.

\section{Modern NEUROSCIENCE, PREFERENCE, AND THE NECESSARY ROLE OF PATHOS IN LOGOS}

\section{A. Emotion and Reason as "Co-Dependent" in the Brain}

As Paul Maharg and Caroline Maughan put it, "[n]ow that we can see much of what is going on inside the brain, the concept of an intelligence quotient as a measure of general intelligence is looking more fluid." 18 Thus, "[w]e are not the rational beings we think we are ... A large part of our frontal cortex is involved with emotion; reason and emotion are codependent." 19 Not surprisingly, therefore, when the brain is damaged in such a way that "we can't grasp our emotions," it also disturbs our ability to make decisions. ${ }^{20}$ Consistent with this insight, people lacking emotions (such as victims of brain damage) can be impaired from making rational decisions. ${ }^{21}$

17. See Bandes, supra note 5, at 2 .

18. Maharg \& Maughan, supra note 12 , at 3.

19. See Maughan, Why Study Emotion?, supra note 1, at 13.

20. Id.

21. Carole Adam, Andreas Herzig, \& Dominique Longin, A Logical Formalization of the OCC Theory of Emotions, 168 SYNTHESE 201, 201 (2009) [hereinafter Adam, Herzig, \& Longin]; see also Maughan, Why Study Emotion?, supra note 1, at 13 (noting that when the brain is damaged "so that we can't grasp our emotions, we don't know what to think and so can't make up our minds about anything"); DANIEL Goleman, The BRAIN AND EMOTIONAL INTElligENCE: NeW INSIGHTS 19-20 (2011) (discussing the case of a "brilliant corporate lawyer" whose brain tumor surgery required cutting "circuits that connect key areas of the prefrontal cortex ... and the amygdala in the midbrain's area for emotions;" thereafter the lawyer's "IQ, memory, and attention" remained unimpaired but he could no longer function as a lawyer because he could no longer "connect his thoughts with the emotional pros and cons"); Rebecca Tushnet, More than a Feeling: Emotion and the First Amendment, 127 HARV. L. REV. 2392, 2392 (2014) ("Scientific evidence indicates that emotion and rationality are not opposed, as the law often presumes, but rather inextricably linked. There is no judgment, whether moral or otherwise, without emotions to guide our choices. Judicial failure to grapple with this reality has produced some puzzles in the law."). 


\section{B. Emotion and Reason as "Co-Dependent" in Practice}

Though contradicting the "commonsensical assumption that emotions prevent agents from being rational," 22 such neuroscience should not surprise anyone who realistically reflects upon the process of decision making itself. Without preference, one is in a "state of indifference... between alternative choices or courses of action." ${ }^{23}$ Perhaps one flips a coin in such a case but in that event the coin rather than the agent "chooses" the result. And the coin, of course, just relocates preference. Have we not preferred the coin toss to no decision at all? Coin toss or not, we thus see the necessary role of preference ("a liking for one thing more than for another" 24 ) in decision making. (Preference also exists at a macro level: we generally prefer to "maximize the experience of positive emotions and to minimize the experience of negative emotions." ${ }^{25}$ )

Of course, we might try to eliminate the affective ${ }^{26}$ here by focusing on behavior and simply defining choice in terms of actual behavior in practice. ${ }^{27}$ Thus, we might say that an agent who rests in place decided to rest in place simply by virtue of the behavior. However, this not only ignores the feelings we all know we have when we make decisions, but also disregards the experiments noted, and showing that people lacking emotions cannot rationally make decisions. ${ }^{28}$ It also leads to the odd result that inanimate things can be said to make decisions. If a car veers to the right, should we not, based on this same logic, say that the car chose to do so? For purposes of this paper, I shall assume that reasonable minds reject

22. Adam, Herzig, \& Longin, supra note 21, at 202; see also Solomon, Emotions and Choice, supra note 12, at 224 (discussing the view that emotions are "the hallmark of the irrational and the disruptive").

23. Indifference, THE PENGUIN DictionaRY of Psychology (4th ed. 2009); see also Maughan, Why Study Emotion?, supra note 1, at 16 ("[M]odern thinking is telling us. . that there is no reasoning without an emotional framework of goals and sub-goals; and there is no effective expression of emotion (except in life-threatening situations) if it is not regulated by our powers of reason.").

24. Preference, The PENGUIN Dictionary OF PSYCHOLOGY (4th ed. 2009)

25. Paul Ekman \& Richard J. Davidson, Epilogue to THE NATURE OF EMOTION: FUNDAMENTAL QUESTIONS 411, 412 (Paul Ekman \& Richard J. Davidson eds., 1994).

26. Again, contemporary usage of "affect" is "very loose;" as noted in Section I above and below, it is a "general term used more or less interchangeably with various others, such as emotion, emotionality, feeling, mood, etc." Affect, The Penguin DictionaRy OF PYSChOlOGy (4th ed. 2009) (italics omitted). I use terms such as "affect" and "affective experience" to include feeling, emotion, and mood as I define those terms in more detail in Sections III and IV below.

27. See Behaviourism, The Penguin Dictionary of Psychology (4th ed. 2009).

28. See Adam, Herzig, \& Longin, supra note 21, at 201. 
such radical behaviorism ${ }^{29}$ and will not waste the reader's time discussing it further.

\section{C. "Co-Dependency" and Modern Notions of Rational Choice}

Better models of rational choice thus expressly examine relations between affective experience and reason including relations between "action, beliefs, desires (or preferences), and information." 30 Not only do we see emotion and reason linked in the brain, we know that we are trapped in a state of inertia unless we have the "arousal and desires to act" that emotion provides. ${ }^{31}$ By definition, decision is not possible in a state of pure inertia. I shall therefore proceed assuming what I see to be obvious: We cannot make rational and voluntary choices that do not involve our preferences and thus do not involve emotions or other affective states. As Rebecca Tushnet puts it, "emotion is a crucial component of decisionmaking" and thus there is "no weighing of alternatives, or judgment between them, without emotions guiding choices." 32

\section{FEELING AND BEYOND: THE BROAD RANGE OF PATHOS AND AFFECTIVE EXPERIENCE}

Recognizing that affective experience plays a role in reason rather than undermining it, we thus need to understand the nature of affective experience itself. Since we often associate emotion and other affective experience with "feeling," what exactly do we mean by "feeling?" Once we know what we mean by "feeling," is affective experience equivalent to "feeling?" If not, must affective experience at least involve "feeling" of some sort? If "feeling" is not required, what must affective experience involve? What distinguishes affective and non-affective experience?

29. See e.g., Behaviourism, The PENGUIN Dictionary OF PSychology (4th ed. 2009) ("Today most psychologists feel uncomfortable with radical behaviourism: there seems to be something unsatisfying about excising the causal role of internal, covert or mental processes in explanations of what it is people do" though "all agree that what people do is the ultimate test."). Of course, terms such as "doing" or "behavior" raise definitional questions as to whether they include, for example, "actions and processes of mind." See Behaviour, THE PENGUIN DictionaRY OF Psychology (4th ed. 2009). Most psychologists today would not rigidly exclude "covert mental constructs ... like schemas, ideas, strategies ... and images" which brings us back to a rejection of radical behaviorism. See id.

30. See Jon Elster, Emotional Choice and Rational Choice, in THE OXFORD HANDBOOK OF Philosophy of EMotion 263, 264 (Peter Goldie ed., 2013) [hereinafter Elster, Emotional Choice].

31. See Emotion, The PENGUIN DiCTIONARY OF PSYCHOLOGY (4th ed. 2009)

32. Tushnet, supra note 21, at 2422. 


\section{A. Feeling as Frequent Part but Not Whole of Affective Experience}

\section{Limitations of Feeling}

Since we all know that feeling often plays a role in affective experience, and since one might be tempted to equate feeling with the whole of such experience, feeling needs to be addressed up front. As James Averill notes, "feeling" is "one of the vaguest terms" in English. ${ }^{33}$ One can "feel" such things as a "prick of a pin," a "touch of velvet," the "cold of a winter day" the "pounding of [one's] heart," "ill," "nauseous," "confused and disoriented," and "knowledgeable or enlightened," just to list a few things one can feel. ${ }^{34}$ In its affective sense, I will use "feeling" to mean a sense, experience, or consciousness of being in some affective state, such as having a certain emotion or being in a certain mood. I will also use it in the broader sense of "experiencing, sensing or having a conscious process." 35

Affective states are no doubt often accompanied by "feeling" in the broad sense just defined. I can, and often do, feel angry or jealous when I am angry or jealous (that is, I often have feelings I associate with anger or jealousy in such cases). However, feeling need not accompany anger or jealousy. As therapy can show us, a person who is angry or jealous is "sometimes the last and not the first to recognize that condition." $36 \mathrm{We}$ may not "feel" the emotion because we are suppressing it or because we are emotionally insensitive. More mundanely, we may not feel an emotion simply because our "affective resources are otherwise deployed." $37 \mathrm{We}$ only have limited energies and may not have sufficient energies in some cases to allocate to feeling. Feelings in fact can even be emotionally misinterpreted: "precisely the same state of physiological arousal [can] be labeled 'joy' or 'fury or 'jealousy' or any of a great diversity of emotional labels depending on the cognitive aspects of the situation." ${ }^{38}$ For example,

33. James Averill, I Feel, Therefore $I$ am-I Think, in THE NATURE OF EMOTION: FUNDAMENTAL QUESTIONS, supra note 25, at 379, 379.

34. Id.

35. Feeling, THE PENGUIN DictionaRy OF PSychology (4th ed. 2009).

36. Averill, supra note 33 , at 379.

37. Justin D'Arms \& Daniel Jacobsen, Demystifying Sensibilities: Sentimental Values and the Instability of Affect, in THE OXFORD HANDBOOK OF PHILOSOPHY OF EMOTION, supra note 30, at 585 , 600 [hereinafter D'Arms \& Jacobsen].

38. Stanley Schachter \& Jerome E. Singer, Cognitive, Social, and Physiological Determinants of Emotional State, in WHAT IS AN EMOTION? CLASSIC AND CONTEMPORARY READINGS, supra note 12, at 110,117 [hereinafter Schachter \& Singer] (discussing various ways subjects interpreted effects of adrenaline injections given the "cognitions available" to them); see also Michael Stocker, The 
the effects of adrenaline injections coupled with appropriate cognitive suggestions can make one think one is experiencing emotions that do not in fact exist. ${ }^{39}$ Additionally, as William James notes, rationality can have its own feelings as well, ${ }^{40}$ and feelings can therefore mix with states that are not otherwise affective. Feelings therefore cannot be a required element of affective experience, and Solomon is thus right when he claims that "one can have an emotion without feeling anything." ${ }^{41}$ Furthermore, even when feeling exists, it cannot be sufficient for emotion. Even if I feel angry, I cannot be angry unless I also believe that someone or something has culpably caused "unjust harm" that I wish to punish. The very definition of anger requires such additional cognitive elements. ${ }^{42}$

\section{Huck Finn and the Benefits of Feeling}

Though feeling is not required for other affective experience to exist, that is not to say that feeling is unimportant. To the contrary, feeling plays important roles in cognition. First, present feelings "play a crucial role in expressing the urgency of emotional situations." 43 Second, lawyers and others need to be attuned in every possible way to their environment, and feelings can often "pick up on something" that may not fit under "a conventional rational category" then available. ${ }^{44}$

A classic fictional example of "picking up on something"45 outside of currently-available rational categories is the so-called "Huck Finn Problem," where Huck refuses to return a slave even though Huck's "rational" and "moral" categories tell him that he is doing evil by not

Irreducibility of Affectivity, in WHAT IS AN EMOTION? CLASSIC AND CONTEMPORARY READINGS, supra note 12, at 258, 261 [hereinafter Stocker, Irreducibility] (noting one might "misidentify" an "emotional state as anxiety or boredom" rather than as anger).

39. Schachter \& Singer, supra note 38, at 112. As Averill also notes, we "can feel angry without being angry" and thus feelings can be "hallucinatory" in that way. See Averill, supra note 33, at 379-80.

40. Williams James, The Sentiment of Rationality, in THE Will To BelieVE AND OTHER ESSAYS IN POPULAR PHILOSOPHY 63, 64 (1956) ("This feeling of the sufficiency of the present moment, of its absoluteness - this absence of all need to explain it, account for it, or justify it-is what I call the Sentiment of Rationality.").

41. Solomon, Emotions and Choice, supra note 12, at 226; see also, Kevin Mulligan, Emotions and Values, in THE OXFORD HANDBOOK OF PHILOSOPHY OF EMOTION, supra note 30, at 475, 476; see also Stocker, Irreducibility, supra note 38, at 263.

42. I set out a more detailed cognitive rubric for anger in the Appendix.

43. AARON BEN-ZE'EV, The SUBTLETY OF EMOTIONS 76 (2000).

44. See Patricia Greenspan, Reasons to Feel, in WHAT IS AN EMOTION? ClassiC AND CONTEMPORARY READINGS, supra note 12, at 265, 267.

45. Id. 
returning the slave. ${ }^{46}$ As Sabine Döring notes, "[i]t is his sympathy for Jim which causes Huck to act ... though he does not endorse his emotion but castigates himself for his weakness." 47 As Döring also notes, in our "default" mode we generally "take the representational content of our perceptions at face value," but these perceptions are not always correct. ${ }^{48}$ As she also notes, much like the Müller-Lyer illusion (where lines refuse to appear of the same length though our ruler tells us that they are), Huck's feelings conflict with his rational judgment. ${ }^{49}$ However, here the feeling did-and should - trump and "need not be an illusion but may equally be adequate to what it purports to represent." 50 If Huck discounts his feeling, he will be doing wrong even though his "rational" categories tell him otherwise. Lawyers, of course, need to recognize that they can have their own "Huck Finn" situations as well.

A striking real example of the evidentiary value of feeling can be found in the interesting case of Lieutenant Commander Michael Riley during the first Gulf War. Riley had to make a fast decision about whether a radar blip was an American fighter jet or an Iraqi missile and correctly concluded it was a missile he should fire upon even though "later analysis of the radar tapes showed it was impossible" to make such a distinction from the radar blip itself. ${ }^{51}$ Around twenty years later, a plausible reason for his right feeling was discovered: "planes and missiles flew at different altitudes which meant that a missile trace would have appeared on the screen eight seconds after" a plane would have appeared. ${ }^{52}$ Thus, consciously unware of what he was doing, Riley was actually "assessing the altitude of the blip." 53 Neuroscience can help explain this "mysterious" behavior, and we as lawyers would be foolish to ignore such science. As Maughan puts it, when "something unexpected turns up, like the slightly odd radar blip,... dopamine cells stop firing and instead send a strong alert signal to the neocortex, the thinking part of the brain," which generates "surprise, shock, fear, panic; adrenaline pours into the bloodstream, your pulse races, your heart thumps, your palms sweat." 54 This forces one "to take notice and act

46. Sabine A. Döring, Why Be Emotional?, in THE OXFORD HANDBOOK OF PHILOSOPHY OF EMOTION, supra note 30, at 283, 285.

47. Id.

48. Id. at 293.

49. Id.

50. Id.

51. See Maughan, Why Study Emotion?, supra note 1, at 11.

52. Id.

53. Id.

54. Id. at 12 . 
immediately." 55 Since the blip did not "feel" like a plane, "Riley did what felt right-he gave the order to fire." ${ }^{56}$ As Maughan also notes, "[t]he point here is that this hits you as a feeling, not a process of reasoning." 57

Though it might at first seem odd to say that feeling can trump reason, it should not for at least a couple of reasons. First, reason employs categories which are always subject to further refinement, ${ }^{58}$ and feeling may indicate the need for such refinement. Second, as I have discussed elsewhere, since we can only understand the world through the way our bodies interact with it, meaning is embodied. ${ }^{59}$ As feelings come from the very bodily interaction with the world that generates meaning in the first place, feelings unsurprisingly play a role in meaning and should not be dismissed offhand. ${ }^{60}$ Additionally, we can no doubt learn over time that certain feelings often accompany certain emotions, and we can therefore consider those feelings as evidence of the associated emotion just as we might consider or use other evidentiary markers learned over time.

\section{B. The Affective as Intentional and Thus Potentially Rational}

As the fictional Huck Finn example and real Michael Riley example show, affective experience can be about objects in the world. Huck "felt" what was right about a slave and Riley "felt" what was right about a radar blip even though they lacked "rational" categories for such experiences. These examples show that affective states can have reference to something,

55. Id.

56. $I d$.

57. Maughan, Why Study Emotion?, supra note 1, at 11. Another interesting case involves a patient of Edouard Claparede. The patient "had apparently lost the ability to create new memories," and the doctor had to reintroduce himself each time he walked into the room. However, on one occasion the doctor concealed a nail in his hand that pricked the patient when they shook hands. The next time the doctor tried to shake her hand, she would not oblige though she could not give a reason. Thus, "subconsciously she had learned that shaking his hand could cause her harm, and her brain used this stored information. Id. at 30-31.

58. See Harold A. Lloyd, Good Legal Thought: What Wordsworth Can Teach Langdell About Forms, Frames, Choices, and Aims, 41 VT. L. REV. 1 (2016); Harold A. Lloyd, Law as Trope: Framing and Evaluating Conceptual Metaphors, 37 PACE L. REV. 89 (2016) [hereinafter collectively Lloyd, Forms \& Trope].

59. See Lloyd, Exercising Common Sense, supra note 2, at 1218 ("This embodied approach recognizes that meaning comes 'via the sensory-motor and emotional systems, which define goals and imagine, recognize, and carry out actions.'").

60. See, e.g., Matthew Ratcliffe, The Phenomenology of Mood and the Meaning of Life, in THE OXFORD HANDBOOK OF PHILOSOPHY OF EMOTION, supra note 30, at 349, 350 [hereinafter Ratcliffe, The Phenomenology of Mood] (noting "we experience the world through our feeling bodies" and distinguishing "intentional and pre-intentional feelings" from inner or outer-directed feelings). 
"to some situation, person, object or state of affairs." 61 When referring to things beyond themselves, emotions have "intentionality," which philosophers define as "that property of many mental states and events by which they are directed at or about or of objects and states of affairs in the world." $" 62$

As affective states can refer to the world, they can thus be judged in terms of how well they refer. For example, if I am angry that someone stole my car, that anger involves a belief about the world, i.e., that someone stole my car. ${ }^{63}$ If my belief is accurate, my anger is well founded and can be useful to the extent it provokes me to remedy the situation. If my belief is wrong, my anger is not well founded and should be assuaged.

Since affective states can be directed at the world, we can interact with the world through them. They can thus help us "apprehend something about the world itself," 64 and they can thereby help us grapple with that world. Rather than always being "irrational and disruptive," affective states can refer to the world in ways that "provide us with information about ourselves and the world." 65 Lawyers wishing to fully grasp clients, issues, and audiences will of course want to understand how affective experience can do this. For example, if I am angry at Atticus Finch because I believe he scratched my car, the object of my anger is Atticus Finch. However, my belief about the car no doubt plays a role here since there would be no anger without my thinking the car was scratched. In evaluating the proper or improper intentionality of such anger, we will need to ask whether the belief about the car is well grounded. Did Finch really scratch the car? My lawyer in such a case must make such inquiries before pursuing the matter. If my belief is wrong, my lawyer must dissuade me from acting. If my belief is right, my anger is justified and can have the positive result of prompting me to pursue justice. (In such cases I find it helpful to distinguish between the "direct object" of the anger-Atticus Finch--and any "indirect objects" in play - such as my car or my belief about the car. If we slip and consider the car the direct object of the anger, we will confuse

61. Calhoun \& Solomon, supra note 6, at 26 .

62. Adam, Herzig, \& Longin, supra note 21, at 204 (citing JOHN R. SEARLE, INTENTIONALITY: AN ESSAY IN THE PHILOSOPHY OF MIND 1 (1983)); see also Harold A. Lloyd, Crushing Animals and Crashing Funerals: The Semiotics of Free Expression, 12 FIRST AMEND. L. REV. 237, 247-48 (2013) [hereinafter Lloyd, Crushing Animals].

63. See Solomon, Emotions and Choice, supra note 12, at 230.

64. Ronald De Sousa, The Rationality of Emotion, in WHAT IS AN EMOTION? CLASSIC AND CONTEMPORARY READINGS, supra note 12, at 248 [hereinafter De Sousa, The Rationality of Emotion].

65. See id. at 249. 
ourselves and lose focus on the need to find any appropriate remedy from the direct object-Atticus Finch.)

\section{The Affective as Intentional and Thus Creative}

Because emotions engage lawyers with the world on multiple additional levels, emotions play a critical role in intellectual and practical creativity. Broadly speaking, as Richard Shweder puts it, an "affective experience is an invitation to wonder why, to ask what those feelings reveal, to investigate various orders of reality (biochemical, interpersonal, moral), to diagnose one's biochemical, interpersonal, and moral standing in the world, and to make plans accordingly." ${ }^{66}$ As Solomon puts it, "[s]ome emotions, for example, scientific curiosity and a love of the truth, are essential to the advancement of knowledge." ${ }^{.77}$ More specifically, for example, fear for one's future career can drive the creativity necessary to find a solution. ${ }^{68}$ Fear of losing a case can do the same as can the joy anticipated from closing a deal. In fact, as we shall see in Section V(D) below, there are no "natural" emotions. Instead, we must be creative in how we define our emotions themselves, and reasonable minds can no doubt creatively challenge and improve the proposed emotional rubrics I have set forth in the Appendix.

\section{The Affective As Intentional With a "Personal Stake"}

\section{1. "Personal Stake" As Differentiating Pathos from Logos}

At this point, since affective states can be rational and rational states can have associated feeling, ${ }^{69}$ the reader has likely begun to wonder just how to distinguish affective from non-affective experience. I would say the distinction turns on whether we have some personal stake or other invested interest. As Robert Solomon notes, through emotions we "constitute and mythologize our world, projecting our values and passing judgments on ourselves and other people, our situations and the various

66. Richard A. Shweder, "You're Not Sick, You're Just in Love": Emotion as an Interpretive System, in The NATURE OF EMOTION: FUndAMENTAL QUESTIONS, supra note 25, at 32, 42 [hereinafter Shweder, You're Not Sick].

67. Robert C. Solomon, Introduction to WHAT IS AN EMOTION? ClASSIC AND CONTEMPORARY READINGS, supra note 12, at 2 [hereinafter Solomon, Introduction].

68. See, e.g., AVERILL \& NUNLEY, supra note 14, at 4-5 (discussing the advanced-degree travails of "Lynn").

69. See Sections III(A),(B) and (C). 
'intentional objects' in which we have invested our interests."70 Robert C. Roberts makes a similar point when he calls emotions "a kind of structured perception" that he calls "concern-based construals." "71 As James R. Averill further puts it: one "feels emotional just to the extent" one "becomes engrossed in an emotional role, like a deep actor who experiences the part he ... is playing." 72

\section{2. "Pensive" vs. "Emotional" Malice}

Affective and non-affective experience can thus present us with fraternal twins that differ only in the presence or absence of a personal stake or personal concern. Malice provides a straightforward example. ${ }^{73}$ The malice involved in a vandal's destruction of a political yard sign can be highly emotional because of the personal interest the vandal takes in the particular election. However, the malice of a rapist who does not know the victim, and has no personal interest in whom he rapes may lack all emotion. For convenience, I will distinguish the non-affective fraternal twin here by calling it "pensive." ${ }^{74}$ Thus, I distinguish here between "pensive malice" and "emotional malice." I discuss in Section VI(B) below why the common law definition of murder uses pensive rather than emotional malice.

\section{A Distinction With a Meaningful Difference}

Distinguishing between "pensive" and "affective" love is not mere pedantic word play. First, as we just saw, there is a real and practical difference in how we deal with situations depending upon whether we have a "personal stake" in them. Second, the law parses such a difference where appropriate, as we will see in the discussion of common law murder in Section VI(B) below. Third, however, careful legal reasoning does not parse between the two where appropriate. For cxamplc, the Fourth Circuit

70. Robert C. Solomon, The Passions: Emotions and the Meaning of Life 153 (1993) [hereinafter SOLOMON, PASSIONS].

71. Robert C. Roberts, Emotions and the Canons of Evaluation, in THE OXFORD HANDBOOK OF PHILOSOPHY OF EMOTION, supra note 30, at 561, 571 [hereinafter Roberts, Emotions].

72. Averill, supra note 33 , at 385.

73. I provide a detailed rubric for malice in the Appendix.

74. This term not only seems pragmatically appropriate, but etymologically appropriate as well. Descartes introduced the term "emotion" ("émotion" in French). See Louis C. Charland, Reinstating the Passions: Arguments from the History of Psychopathology, in THE OXFORD HANDBOOK OF PHILOSOPHY OF EMOTION, supra note 30, at 238, 240 [hereinafter Charland, Reinstating the Passions]. "Pensive" also comes from the French via the Old French word "penser" meaning "to think." Pensive, THE AMERICAN Heritage COLlege Dictionary (4th ed. 2001), 
has stricken provisions of North Carolina's voting laws "enacted with racially discriminatory intent," suggesting that "any member of the General Assembly harbored racial hatred or animosity toward any minority group."76 Pensive racial discrimination was more than enough reason to strike the law; emotional racial discrimination was not also required. ${ }^{77}$ Fourth, as Aristotle notes, pathos is one of the fundamental means of persuasion. ${ }^{78} \mathrm{By}$ better understanding the difference between pathos and logos, we will be able not only to use pathos but also to avoid confounding pathos and logos.

\section{DistingUISHING AFFECTIVE STATES BASED ON TYPE OF INTENTIONALITY, OCCURRENCE STATUS, AND DURATION}

Now that we have explored the intentionality of affective experiences, we can refine them into four basic types based upon their objects, their "occurrent or dispositional nature," and their duration. ${ }^{79}$

\section{A. Emotion: Specific Intent, Occurrence, and "Short" Duration}

Aaron Ben-Ze'ev usefully distinguishes emotion from other affective experience by its "specific intentionality" and by its "occurrent state"; emotion is live and directed at specific objects. ${ }^{80}$ To be angry, for example, I must be angry about something or someone and the state must exist now rather than being a mere disposition toward anger. Additionally, emotion is generally considered short term. ${ }^{81}$ Beginning with Section $\mathrm{V}$ below, I will return to emotion in more detail and will thereafter focus on emotion for the remainder of the article.

\section{B. Sentiment: Specific Intent, Disposition, and "Longer" Duration}

Additionally, Aaron Ben-Ze'ev usefully distinguishes sentiment from other affective experience by its "specific intentionality" and its

75. N. C. State Conference of NAACP v. McCrory, 831 F.3d 204, 219 (4th Cir. 2016).

76. Id. at 233.

77. See id. at $219,233$.

78. See Aristotle, ON Rhetoric: A Theory of Civic Discoursf Rook 2.1.2-3 (George Alexander Kennedy trans., 1991) ("Pathos is to be awakened within the audience so as to induce them to make the judgment desired; men change their opinions in regard to judgment ... as such, emotions have specific causes and effects.").

79. See BEN-ZE'EV, supra note 43 , at 80 .

80. See id.

81. Emotion, THE OXFORD DictionaRY OF PSYCHOLOGY (3d ed. 2009). 
"dispositional state;" sentiment is directed at specific objects but is not always "live." 82 Instead, it involves a disposition to have a certain experience or experiences. ${ }^{83}$ For example, I may have an enduring anger which is not always "live" but which I am disposed to express over some enduring length of time. ${ }^{84}$ Similarly, I may have an "enduring love" of someone even though I think of them infrequently. ${ }^{85}$

\section{Mood: General Intent, Occurrence, and "Short" Duration}

Aaron Ben-Ze'ev further distinguishes mood from other affective experience by its "general intentionality" and by its "occurrent state;" mood is live but is directed generally at the world or all experience rather than at specific objects. ${ }^{86}$ Such mood states can include, for example, "being cheerful, satisfied, 'blue,' and gloomy." ${ }^{87}$ Moods can be both "short-lived" and "sustained."

Anxiety is a prototypical mood. Robert Solomon defines anxiety as "fear of everything" (thus addressing its general intentionality) ${ }^{89}$ For him, the accompanying narrative is " $t]$ he most Baroque-like portrait of hell, with every turn a torture, every creature a devouring monster, every companion a torturer, every space a prison, every move a risk." ${ }^{90}$ of course, anxiety can be of a lower grade involving a "vague, unpleasant emotional state with qualities of apprehension, dread, distress and uneasiness." ${ }^{\text {"Il }}$ In any case, the mood of anxiety differs from the emotion of fear because the mood is "objectless, whereas fear assumes a specific feared object." $" 92$

Lawyers and others should also recognize that mood can serve a deep intentional role. Not merely always "generalized emotions," they can serve as "part of the background structure of intentionality" making intentionality

82. See BEN-ZE'EV, supra note 43 , at 80 .

83. See id.

84. See Charland, Reinstating the Passions, supra note 74, at 238 ("[sentiments] are affective orientations that endure over long periods of time").

85. See BEN-ZE'EV, supra note 43 , at 80.

86. See id. at 81; SOLOMON, PASSIONS, supra note 70, at 71 ("a mood enlarges its grasp to attend to the world as a whole")

87. BEN-ZE'EV, supra note 43, at 81 .

88. Anxiety, The Pengun Dictionary of Psychology (4th ed. 2009).

89. SOLOMON, PASSIONS, supra note 70 , at 230.

90. Id. at 231 .

91. Anxiety, THE PENGUIN DictionaRy OF Psychology (4th ed. 2009).

92. Id. 
itself possible..$^{93}$ For example, it is hard to imagine how we could believe that a project might succeed unless we are in a sanguine mood consistent with such belief. ${ }^{94}$ This is not to say that "all moods are pre-intentional" or that "all pre-intentional backgrounds are moods." 95 However, we can see how mood plays a pre-intentional role as Heidegger famously noted with his notion of "being tuned" to the world. ${ }^{96}$

\section{Trait: General Intent, Disposition, and "Longer" Duration}

Finally, Aaron Ben-Ze'ev helpfully distinguishes an "affective trait" by its "general intentionality" and "dispositional state;" like mood, an affective trait is not directed at specific objects, but unlike mood it is not "live," but rather involves a disposition to have a certain experience or experiences. ${ }^{97}$ Such "affective traits" can include such traits as "shyness and enviousness." $" 98$ Traits can also exist at more fundamental levels. For example, Ben-Ze'ev would distinguish between two types; "[h]ighly emotional people perceive the events of their daily lives as being more significant than do those with less emotional sensitivity" and their world is thus "a place where many events assume great significance." " On the other hand, "[p] eople of low emotional sensitivity have to look for unique events, or even create unique events (e.g., a mountain climbing expedition), in order to be confronted with such significant events."100

As traits have some stability through time, savvy lawyers will of course want to know both their own and others' traits as best they can and plan and act accordingly. Unlike more short-term affective states, traits can permit greater predictability.

93. See Ratcliffe, The Phenomenology of Mood, supra note 60, at 350.

94. Id. at 354 .

95. Id.

96. SOLOMON, PASSIONS, supra note 70, at 112.

97. BEN-ZE'Ev, supra note 43, at 81 ; see also Trait, THE PENGUIN DictionaRY OF PSYCHOLOGY (4th ed. 2009) ("[A]ny enduring characteristic ... that can serve an explanatory role in accounting for observed regularities and consistencies in behaviour" though it is "misleading to use [the term] for the regularities themselves.").

98. BEN-ZE'EV, supra note 43, at 81.

99. Id. at 151 .

100. Id. 


\section{FOCUSING FURTHER ON EMOTION: ELEMENTS AND OPTIONS}

\section{A. Levels of Describing Emotion}

Having laid the general groundwork for understanding affective experience, which should be of general interest and use to lawyers, I will now explore the specific topic of emotion itself in more detail before turning to sample specific areas of emotion of particular interest to lawyers (which sample areas are by no means exhaustive of the ways emotion should and does interest lawyers).

As Aaron Ben-Ze'ev notes, emotions are "complex phenomenon describable on different levels, for example, physiological, biological, psychological, sociological, or philosophical."101 Much like Ben-Ze'ev in his work, I will focus on "the psychological and philosophical levels" of emotion. ${ }^{102}$ For me as well, the psychological level includes "feeling, cognition, evaluation, and motivation" 103 and the philosophical level includes "the rationality of emotions." 104 This all includes recognizing that emotional states can "tend to have motivational properties." 105 If I am afraid, for example, I wish to avoid some perceived danger and am likely to be motivated to flee or to hide as seems most prudent in the particular circumstances. ${ }^{106}$

\section{B. Necessary Elements of Emotion}

Focusing on psychological and philosophical levels of description in light of the discussion above, emotion as a "short-term evaluative, affective, intentional, psychological state"107 necessarily involves (1) an object, (2) a personal stake or concern, (3) an appraisal or other cognitive response, (4) a resulting desire or motivation, (5) core themes that distinguish one emotion from another, and (6) acuteness. As we shall also see, emotion may also (but need not) include (7) feeling, and (8) action tendencies. Understanding each of these necessary and optional components of emotion is critical for the lawyer who would understand both emotion in legal reasoning and emotion in the reasoning of clients,

\footnotetext{
101. Id. at 10 .

102. Id.

103. $I d$

104. BEN-ZE'EV, supra note 43, at 10

105. See Motivation, The Penguin Dictionary of Psychology 447-48 (4th ed. 2009)

106. I discuss the aspects of fear in more detail in the Appendix.

107. Emotion, THE OXFORD DICTIONARY OF PSYCHOLOGY (3d ed. 2009),
} 
judges, and all others with whom the lawyer must deal. Other than acuteness, which seems self-explanatory, and "personal stake," which I believe I have adequately discussed in Section III(D) above, I will briefly survey each component in the order set forth above.

\section{Object}

As our prior discussions have shown, "[a]s a matter of logic, every emotion has its particular object." 108 One cannot, for example, love without loving someone or something. The object can be fictional or otherwise lack physical existencc. ${ }^{109}$ For example, we can be proud of a fictional character that we created in a novel or other work. When focusing on the object of an emotion, we necessarily focus on a particular aspect or interpretation of that notion, since we do not experience things in themselves apart from our interpretative categories. ${ }^{110}$

Such aspects and interpretations of objects of emotion certainly involve the concepts and narratives that we bring to such experience. No doubt most people would find it hard to see how "one can have any experiential sense at all without elaborating, interpreting, labelling or recognizing what the experience is." 111 Though it may be obvious to most people that we cannot think without concepts or ideas, the inextricable role of narrative with such concepts and ideas may not be as obvious. Since we think with stories, ${ }^{112}$ cognitive aspects of affective experience must also involve "stories we tell ourselves in order to guide and account for our own behavior."113 I further discuss these topics of concepts and narratives in Section V(B)(2) below on appraisal. ${ }^{114}$

Of course, by the same logic, narrative plays a necessary role in the very definition of affective experience itself. For example, Richard A.

108. SOLOMON, PASSIONS, supra note 70 , at 112.

109. See Calhoun \& Solomon, supra note 6, at 26.

110. See id. at 28 (on aspect); see also Errol Bedford, Emotions, in WHAT IS AN EMOTION? CLASSIC AND CONTEMPORARY READINGS, supra note 12, at 207, 216 [hereinafter Bedford, Emotions] ("Emotion concepts... presuppose concepts of social relationships and institutions, and concepts belonging to systems of judgment, moral, aesthetic and legal.").

111. Sensation, THE PENGUIN Dictionary of PsYCHOLOGY (4th ed. 2009).

112. See generally Harold Anthony Lloyd, Narrative in Law and Life: Some Frequently Asked Questions (FAQ's), THE SECOND DRAFT, Fall 2015, at 2, 2 [hereinafter Lloyd, Narrative].

113. See Averill, supra note 33, at 385 .

114. For additional discussion of the role of concepts in framing our experience, see generally Lloyd, Forms \& Trope, supra note 58. For an additional brief overview of the role of narrative in such framing, see generally Lloyd, Narrative, supra note 112, at 3. 
Shweder notes three "general kinds" of "folk theories of ... affective experience." 115 These three theories are: "(1) theories of 'sickness' (a biochemical theory); (2) theories of 'bewitchment' (an interpersonal theory); and (3) theories of 'suffering' (a moral theory)."116 Theories of "bewitchment" can involve such tales as a "ghost attack," and theories of "suffering" can involve tales of sin and just deserts. ${ }^{117}$ In the west, we have moved from such supernatural narratives to tales of the affective in terms of "mental or psychosomatic causation." 118 Given that different languages and cultures can tell quite different narratives, it seems apparent that emotional or other affective terms will not always match "neatly across language and cultural boundaries."119

\section{Appraisal: Mechanics, Concepts, Narratives, and Lawyer Checklists}

Once we have identified some person, place, thing, or event in which we have a personal stake or personal concern, it would generally be odd to ignore such a person, place, thing, or event without at least some further thought or appraisal, even if such further thought or appraisal is merely to conclude that such object merits little further attention at the moment. How do we typically go about such emotional evaluation or appraisal?

Klaus R. Scherr provides us with a useful summary of "five major checks" often involved in emotional appraisals of experiences we encounter. First, there is often a "novelty check" to see whether we are faced with "a change in the pattern of external or internal stimulation." 120 Second, there is often an "intrinsic pleasantness check" to determine "whether a stimulus event is pleasant or unpleasant."121 Third, there is often a "goal/need significance" check as to "whether a stimulus event is relevant to important goals or needs ...." "122 Fourth, there is often a "coping potential check" regarding both the "causation of stimulus event" and the "coping potential available to the organism" in light of the type of

115. Shweder, You're Not Sick, supra note 66, at 41.

116. Id.

117. See id.

118. See id.

119. See id. at 33

120. Klaus R. Scherr, Evidence for Both Universality and Cultural Specificity of Emotion Elicitation in THE NATURE OF EMOTION: FUNDAMENTAL QUESTIONS, supra note 25, at 172, 174.

121. Id.

122. Id. 
causation. ${ }^{123}$ Fifth, there is often a "norm/self compatibility check" regarding conformance with applicable norms. ${ }^{124}$

Scherr's "five major checks" unsurprisingly provide a nice "macro" list for lawyers presented with problems. First, is there some precedent for the matter or must we work from scratch? Second, is the matter pleasant or unpleasant to the client, and how should this drive our representation of the client? Good lawyers, like good doctors, should also have good bedside manners. Third, apart from how the client perceives the matter, how does the matter actually fit in with the client's true goals and needs? Fourth, what are the various options actually available to the client? Fifth, which of these options is normatively best for that particular client? That is, which option not only best suits the particular client but is also best grounded in law and ethically right?

In performing our appraisal checks, we must use the concepts and narratives noted above. At the most obvious level, we must examine the particular surface concepts and narratives in play. If I am angry at someone for stealing my car, the surface narrative and concepts are how the person went about taking the car. However, concepts and narrative also come into play at deeper levels. We have "paradigm" scenarios for affective experience that give us the vocabulary that we need to tell our stories. ${ }^{125}$ Theft is wrong, and thus merits anger; we can reinforce and expand this commonplace scenario with "the stories, art, and culture to which we are exposed" through life. ${ }^{126}$ From childhood we learn that "by taking a sequence from an emotional scenario out of context, one can play-act or 'pretend' emotions that are not actually being felt." 127 This allows us both to develop affective skills and to use emotion for various goals as noted above.

As we grow, we also learn that the concepts and the "stories that help constitute our feelings are never complete" but are "always open to 'editorial revision."'128 We learn as we grow and we write and revise our

123. Id.

124. Id.

125. See De Sousa, The Rationality of Emotion, supra note 64, at 255; see also Shweder, You're Not Sick, supra note 66, at 32 (Each emotion names a "particular story-like, script-like, or narrative kind that any people in the world might (or might not) make use of to give meaning and shape to their somatic and affective 'feelings."').

126. See De Sousa, The Rationality of Emotion, supra note 64, at 255.

127. See id. at 256 .

128. See Averill, supra note 33, at 385 . 
own "scripts for our emotional stories" using our "past experiences, present circumstances, and future aspirations." 129 Good scripts take careful account of such experiences and circumstances and do not fail to recognize how they have actually unfolded over time.

\section{Desire or Motivation}

After making the sorts of checks discussed above, one must recognize and analyze any resulting desired actions. Given this relation between appraisal and desire, emotion is commonly understood to include "desires to act," $" 130$ and we will want to explore the desires specific to different emotions. I do this with respect to the specific emotions otherwise addressed in this article and in the Appendix.

\section{Distinctive "Core Themes"}

Psychologists and philosophers have tried to determine "core relational themes" for specific emotions in order to tie these above aspects of emotion together in express ways. ${ }^{131}$ Finding such inquiry useful as well, I classify individual emotions using a simple rubric containing four elements: object, appraisal, narrative, and desire. Such a rubric assumes personal stake or concern and assumes that appraisal occurred in the manner described above.

\section{a. Hatred and Employment Discrimination}

For the purpose of giving an initial example of such an emotion rubric, I accept the following definition of "hatred:" a "deep, enduring, intense emotion expressing animosity, anger and hostility" which is "usually assumed to [include] ... the desire to harm or cause pain to the object of the emotion ...."132 Assuming the object of hatred to usually be a sentient creature or at least one perceived to be sentient (since it is hard to imagine

129. See id.

130. See Emotion, The PEnguin Dictionary of Psychology (4th ed. 2009); see also Elster, Emotional Choice, supra note 30, at 264.

131. See Richard Lazarus, Appraisal: The Long and the Short of $I$, in THE NATURE OF EMOTION: FUNDAMENTAL QUESTIONS, supra note 25, at 208, 210 [hereinafter Lazarus, Appraisal]; see also BEN ZE'EV, supra note 43, at 31 (speaking of "core evaluative themes"); SOLOMON, PASSIONS, supra note 70 , at 223 ("each emotion is a characteristic set of . . judgments (and desires, intentions, and strategies)"').

132. Hatred, THE PENGUIN DictionaRy OF PSyChOlOGy (4th ed. 2009). 
how one could cause pain to something lacking feeling), ${ }^{133}$ my fourelement approach to a rubric for the emotion of hatred could thus read as follows:

\begin{tabular}{|l|l|}
\hline $\begin{array}{l}\text { Prototypical Direct } \\
\text { Object }\end{array}$ & Anything perceived as sentient. \\
\hline Prototypical Appraisal & $\begin{array}{l}\text { The Direct Object as evil and thus deserving } \\
\text { pain or other harm. }\end{array}$ \\
\hline Prototypical Narrative & "[A] battle between good and evil."'135 \\
\hline Prototypical Desire & $\begin{array}{l}\text { To cause pain or other harm to the Direct } \\
\text { Object and to have righteous pleasure doing } \\
\text { so. }\end{array}$ \\
\hline
\end{tabular}

Likewise, a rubric for a specific case of hatred involving a bigoted employer and a gay employee that a lawyer might find in practice could read as follows:

\begin{tabular}{|l|l|}
\hline Actual Direct Object & The employee. \\
\hline Actual Appraisal & The employee as gay and thus immoral. \\
\hline Actual Narrative & $\begin{array}{l}\text { Evil gay people pushing their evil agenda on good } \\
\text { people. }\end{array}$ \\
\hline Actual Desire & $\begin{array}{l}\text { To harm the employee by firing him and to have } \\
\text { righteous pleasure by doing so. }\end{array}$ \\
\hline
\end{tabular}

Such rubrics not only help lawyers and others identify specific emotions but also help them identify and address specific examples of those emotions in play. They also help them distinguish between emotions that might otherwise be confused.

133. See SOlOMON, PASSIONS, supra note 70, at 264 (considering a "person" as the typical object). Recalling Ahab's hatred of Moby Dick, for example, it is hard for me to limit the object here to persons rather than the broader class of anything perceived to be sentient. I recognize reasonable minds can differ on the potential range of objects for given emotions, and I wish here only to take the position I consider reasonable. I consider the evaluation of objects of actual emotion more interesting and important than such abstract discussion and propose this rubric with those actual objects in mind. Thus, if someone wants to say that they specifically hate "spinach" as well as certain people, I would indulge them the discussion. See id. (Solomon notes he is excluding the example of spinach for purposes of his discussion).

134. See also Section III(B) above, Section VI(C)(1), and the Appendix where I distinguish between possible direct and indirect objects of emotion. In the interest of space, I do not attempt to lay out any such indirect objects of the various emotions.

135. SOLOMON, PASSIONS, supra note 70, at 266; see also Elster, Emotional Choice, supra note 30 , at 268 (hatred based on belief that the person hated is "evil").

136. Specific narratives on a prototypical theme of course have infinite possible permutations. We need to understand the specific permutation in play if we wish to address the situation effectively. 


\section{b. Disgust and Employment Discrimination}

For example, one might compare disgust with hatred using the following definition of disgust: "[1]iterally, a bad taste ... a negative emotional state that follows exposure to a stimulus that is unpleasant but not an immediate physical threat" that "involves active rejection of the stimulus." ${ }^{37}$ Disgust can also involve fear of contamination: "moral disgust arises most typically in the case of norms that involve bodily contact and bodily fluids - potentially sources of contamination." 138 Thus, with disgust we "want to distance ourselves from the things that disgust us." 139 Using these definitions, one can construct the following rubric for disgust:

\begin{tabular}{|l|l|}
\hline $\begin{array}{l}\text { Prototypical Direct } \\
\text { Object }\end{array}$ & Anything. \\
\hline Prototypical Appraisal & $\begin{array}{l}\text { The Direct Object as unpleasant or } \\
\text { contaminating (or both) and thus requiring } \\
\text { active rejection. }\end{array}$ \\
\hline Prototypical Narrative & $\begin{array}{l}\text { Life's inclusion of avoidable unpleasantness and } \\
\text { contamination. }\end{array}$ \\
\hline Prototypical Desire & $\begin{array}{l}\text { To avoid, reject, remove, or disgorge the Direct } \\
\text { Object. }\end{array}$ \\
\hline
\end{tabular}

A rubric for a specific case of disgust involving a bigoted employer and a gay employee could thus read as follows:

\begin{tabular}{|l|l|}
\hline Actual Direct Object & The employee. \\
\hline Actual Appraisal & $\begin{array}{l}\text { The employee as gay and thus a possible } \\
\text { contaminant of other employees with his } \\
\text { "agenda" and diseases. }\end{array}$ \\
\hline Actual Narrative & $\begin{array}{l}\text { Gay people forcing their immoral "agenda" and } \\
\text { spreading fatal diseases disproportionately } \\
\text { caused by that "agenda." }\end{array}$ \\
\hline Actual Desire & To remove the contaminant by firing him. \\
\hline
\end{tabular}

137. Disgust, The Penguin Dictionary of Psychology (4th ed. 2009)

138. Jessie J. Prinze, The Moral Emotions, in THE OXFORD HANDBOOK OF PHILOSOPHY OF EMOTION, supra note 30, at 519, 525 [hereinafter Prinze, Moral Emotions].

139. Id. Consistent with this distancing desire, "we won't drink from a cup . . . used to transport a urine sample, even if we know it has been sterilized." Id. 
As such a rubric demonstrates, addressing the employer who acts out of disgust requires a different rubric than that involved in addressing the employer who acts out of hatred. Though the unfortunate employee is fired either way, the firing motivated by hatred involves an express wish to harm, whereas the firing motivated by disgust need involve no intent to harm the employee. Is a firing based on pure misplaced disgust ${ }^{140}$ somehow less heinous than a firing based on hatred, which necessarily involves an intentional wish to harm? Rephrasing that question in perhaps better legal form, should intent to harm the employee be an element of a discriminatory discharge claim in such a case? If we want to protect employees from bigotry, it is hard to see how intent to harm should be a required element. Since hatred requires intent to harm, it is easy to stray in analysis here if our paradigm for bigotry involves hatred. We get ourselves back on course by recognizing that discrimination can be motivated by emotions other than hatred. We need to look at those other emotions as well (and thus consider more than just hate bigots but also disgust bigots, fear bigots, and bigots motivated by other emotions) to assure that our non-discrimination rules are drafted in ways that capture all the emotions that might prompt an impermissibly-discriminatory firing. For example, the Fourth Circuit struck provisions of North Carolina's voting laws "enacted with racially discriminatory intent" while also noting that the court was not suggesting that "any member of the General Assembly harbored racial hatred or animosity toward any minority group."141 Again, pensive racial discrimination was more than enough reason to strike the law; emotional racial discrimination was not also required. ${ }^{142}$ Doing all this also helps us come up with a good definition of "bigot" itself that does not include elements such as hatred when they would prove extraneous. ${ }^{143}$

\section{c. Why Lawyers Should Parse Emotions Carefully}

This example also shows how parsing between emotions such as hatred and disgust can make a practical as well as a purely rule-based difference. If an employer has a homophobic workforce, for example, there might well

140. Disgust and hate are not mutually exclusive. A firing could of course be driven by both emotions.

141. NAACP v. McCrory, No. 16-1468, 2016 WL 4053033, at *57 (4th Cir. 2016).

142. See id.

143. One definition of "bigot" is: "One who is strongly partial to one's own group, religion, race, or politics and is intolerant of those who differ." Bigot, AMERICAN HERITAGE COLLEGE DictionaRY (4th ed. 2001). Though hatred is not included here, other requirements such as partiality to "one's own group, religion, race or politics" are included. Is this precisely reflective of emotional reality? Are there no self-hating or self-disgusted bigots? 
be more hope for reforming that workforce if it is motivated by some forms of disgust rather than hatred. Hatred based on the belief that someone is inherently evil is beyond all hope of scientific disproof. However, disgust based on the misinformed notion that all gay people spread deadly diseases, for example, is subject to scientific disproof, and workforce education might have some reasonable chance of success in such a case. In saying that, however, I do not naively mean to suggest that disgust bigotry is necessarily less stubborn than hate bigotry. Instead, I just want to point out that their difference can have potentially different remedial implications.

Additionally, lawyers wishing to use pathos in effective legal rhetoric will want to have good rubrics for both the prototypical and specific forms of the emotion involved, including the critical prototypical and specific narratives driving the emotion. ${ }^{144}$ If a speaker wants to anger an audience, for example, that speaker needs to know what can be direct objects of anger and what are typical appraisals, narratives, and desires associated with anger. I have set out a rubric for anger in the Appendix.

\section{Optional Accompaniments of Emotion}

In addition to the necessary elements of emotion discussed above, emotion can also include additional components such as feeling and action tendencies.

\section{Feeling}

As discussed in Section III above, feeling need not accompany all affective experience. That said, however, we all know that feeling often (if not most always) accompanies emotion. ${ }^{145}$ When we have such feeling, we can take it as evidence that emotion may cxist, evidence that we weigh as appropriate in the circumstances. As discussed in Section III above, we should also listen to our "Huck Finn" feelings, which might give us insights otherwise unavailable with our current concepts and narratives. What we should not do, however, is believe that our emotions are reducible to any such feelings.

144. Disgust is also discussed further infra in Section VI and in the Appendix.

145. See Solomon, Emotions and Choice, supra note 12, at 226 ("Emotions typically involve feelings" and may even "essentially involve feelings," but "feelings are never sufficient to differentiate and identify emotions, and an emotion is never simply a feeling."). 


\section{Action Tendency vs. Desire}

No doubt certain emotions often have specific responses associated with them. Fear is a classic example we all know. If something frightens us, we often tend to want to flee. Thus, some like Frijda hold that "[e]ach emotion has associated with it a characteristic action tendency ... an incipient action, a state of readiness of the organism, including a desire to act in a certain way," and context determines "[w]hich of the several possible emotions and action tendencies" are triggered. ${ }^{146}$

Though it is useful to know that fear can often cause one to flee, I am reluctant to define emotions in terms of such action tendencies. First, of course, a paralyzed person cannot flee without assistance and may in fact have come up with other unique coping mechanisms that suit her. ${ }^{147}$ Second, the real constant in the case of fear is the desire to avoid some perceived danger, a desire sometimes met by flight, sometimes met by hiding in place, and sometimes met by other strategies. I, therefore, prefer to focus on prototypical desires or motivations rather than prototypical responses when I try to differentiate the various emotions. Thus, as discussed above, ${ }^{148}$ when trying to set out a rubric for hatred, it is the desire to harm and cause pain that is central to hatred. Therefore, I include desire when setting out the rubric for hatred but do not include candidates for "common responses" or "action tendencies" which may or may not occur and which may or may not be of a "typical" pattern in any particular case.

\section{No "Natural" Emotions}

The fact that emotions have optional accompaniments should also raise doubts that there are universal emotions found across all societies and cultures. Though psychologists and philosophers differ on whether there are such emotions, ${ }^{149}$ the role of the conceptual in emotions should also

146. Elster, Emotional Choice, supra note 30, at 271 (emphasis omitted).

147. See BEN ZE'EV, supra note 43, at 62 (Ben-Ze'ev claims that a person "suffering from total paralysis may have emotions, although ... unaccompanied by any muscular activity. But even in such cases the action tendency is present."). It seems odd to me to say that one can have a tendency to do what one cannot do.

148. See Prinze, Moral Emotions, supra note 138, at 525.

149. See Calhoun \& Solomon, supra note 6, at 25; Paul Ekman, All Emotions are Basic, in THE NATURE OF EMOTION: FUNDAMENTAL QUESTIONS, supra note 25, at 18 [hereinafter Ekman, All Emotions are Basic] (claiming that "[a] distinctive universal signal has been identified for anger, fear, disgust, and sadness"); Patricia Greenspan, Learning Emotions and Ethics, in THE OXFORD HANDBOOK OF PHILOSOPHY OF EMOTION, supra note 30, at 540 [hereinafter Greenspan, Learning Emotions and 
raise doubts such universal emotions exists. It is thus hard to deny that "insofar as emotions involve concepts and beliefs, they may also be learned in a particular culture and, perhaps, learned somewhat differently in different cultures." 150 Jean L. Briggs, for example, claims that "certain Eskimo tribes do not get angry" and even lack such a word with the closest being "childish."151 Similarly, Catherine Lutz rejects "natural emotions"152 by noting Ifaluk examples. Ifaluk "song" cannot be precisely translated as "anger," 153 and their "emotion of fago" invites a complex description for which we have no counterpart in English: "compassion/love/sadness." 154

In addition to the conceptual, belief, and actual field examples suggesting no universality of emotion, any evolutionary reasoning ${ }^{155}$ supporting universal emotions seems to run the other way. First, looking backwards, why would we not assume that different groups of people would not evolve differently in ways that better suit their social and physical environments? Second, since problems can be adequately solved in different ways, why would we think diverse groups would always pick the same solutions? Third, looking forward, would we not expect and want to continue to evolve emotionally as the world changes over time? Would we not want such emotional flexibility and creativity? ${ }^{156}$ I think we would and do in fact have such flexibility since we can change our concepts and beliefs. It is thus hard to deny that "[i]n the final analysis, we are the artificers of our own emotions." 157

\section{EMOTION AND THE LAW: THREE ADDITIONAL SPECIFIC TOPICS}

Having explored emotion both generally and specifically, I will finish by exploring three additional areas in which emotion plays a role both in law and in the lives of lawyers. Each of these topics is a potential subject

\footnotetext{
Ethics] (arguing that if such universality exists, one might try to explain it in as being "programmed into us by evolution"). However, for the reasons given below, I reject any notion of such universality.

150. Calhoun \& Solomon, supra note 6 , at 33.

151. Id. at 34 .

152. Catherine Lutz, Unnatural Emotions, in WHAT IS AN EMOTION? ClASSIC AND CONTEMPORARY READINGS, supra note 12, at 146-47 [hereinafter Lutz, Unnatural Emotions].

153. Id.

154. Id. at 150-51.

155. Id.

156. See James R. Averill, Emotions Unbecoming and Becoming, in THE NATURE OF EMOTION: FUNDAMENTAL QUESTIONS, supra note 25, at 265, 268-69 [hereinafter Averill, Emotions Unbecoming] ("If a change in rules proves effective, we may speak of emotional creativity" and rules should thus be able to evolve. Averill also astutely notes that without constitutive rules, we would be "emotionally inarticulate" and not more free, a general point about rules that lawyers also need to remember.).

157. AVERILL \& NUNLEY, supra note 14, at xii (italics omitted).
} 
itself for volumes of work, and they hardly exhaust the many areas where law and emotion intersect.

\section{A. Emotion as Expression and the First Amendment}

Given the cognitive nature of emotion, there can be no doubt emotion involves expression. In fact, this expression exists on both general and specific levels, and those who understand the nature of emotion cannot reasonably maintain that emotion (whether pensive or affective) does not involve expression. We can take again the emotion of hatred discussed in Section $V(B)(4)(a)$ above. As noted, hatred has a prototypical form involving much expression:

\begin{tabular}{|l|l|}
\hline $\begin{array}{l}\text { Prototypical Direct } \\
\text { Object }\end{array}$ & Anyone or anything perceived as sentient. \\
\hline Prototypical $\Lambda$ ppraisal & $\begin{array}{l}\text { The Direct Object as evil and thus deserving pain } \\
\text { or other harm. }\end{array}$ \\
\hline Prototypical Narrative & "[A] battle between good and evil."158 \\
\hline Prototypical Desire & $\begin{array}{l}\text { To cause pain or other harm to the Object and to } \\
\text { have righteous pleasure doing so. }\end{array}$ \\
\hline
\end{tabular}

This form for hatred thus underlies specific cases of hatred such as, again, one involving a bigoted employer who fires a gay employee:

\begin{tabular}{|l|l|}
\hline Actual Direct Object & The employee. \\
\hline Actual Appraisal & The employee as gay and thus immoral. \\
\hline Actual Narrative & $\begin{array}{l}\text { Evil gay people pushing their evil agenda on good } \\
\text { people. }{ }^{159}\end{array}$ \\
\hline Actual Desire & $\begin{array}{l}\text { To harm the employee by firing him and to have } \\
\text { righteous pleasure by doing so. }\end{array}$ \\
\hline
\end{tabular}

There is thus no doubt that such hatred involves much expression on both general and specific levels. The employer's expression includes: (i) embracing a general narrative about the "gay agenda," (ii) embracing a specific narrative about the employee advancing that agenda, (iii) embracing a specific narrative about how firing that employee will fight back against that agenda, and (iv) expressing a narrative about the

158. Solomon, PAssions, supra note 70, at 266; see also Elster, Emotional Choice, supra note 30 , at 268 (hatred based on belief that the person hated is "evil").

159. Specific narratives on a prototypical theme have infinite possible permutations. We need to understand the specific permutation in play if we wish to address the situation effectively. 
employer itself and a conservative organization that stands up for what it believes is right. The employee also likely has cognitive emotions here including counter narratives at multiple levels about society, morality, the employer, and the employee. The employee likely embraces quite different narratives about gay people in society and the common bigotry against them, about how the employee has no other "agenda" other than to do good work on the job, and about the specific employer's bigotry. As this example shows, emotion not only involves much expression in the emotional person but also provokes much emotional counter-expression when parties interact.

Therefore, thorough First Amendment analysis must examine how and what an individual expresses through emotion and whether protection of any such forms of emotional expression advances the underlying rationales for the First Amendment. It must also examine emotional counterexpression and other rights of those encountering emotional expression. Such further analysis necessarily requires balancing of rights of all the parties involved. Such balancing not only requires examining emotional counter-expression but also examining how emotional expression may harm others thereby generating conflicting claims of right. In this discussion, I can only highlight some of the directions such inquiries might take.

\section{Signifiers and the Mechanics of Expressing Emotion}

To balance rights here, one must understand the mechanics of emotional expression. If, for example, the same emotion could be expressed in multiple ways, only one of which does not harm others, then perhaps we might permit only the non-harmful expression. That would seem an easy balancing act since it would allow expression while doing no harm to others. (I am making a logical point here-I do not claim here that such balancing is always so easy in actual practice.)

To perform such balancing, one must recognize that emotion-like other expression - is expressed or signified in at least three ways: by symbols (arbitrary signifiers such as words or obscene gestures), by "icons" (signifiers resembling what they signify such as a drawing showing the firing of an employee), and by indexes (signifiers that "participate in" the matter expressed such as a red face indicating anger). ${ }^{160}$ Perhaps one type

160. See Lloyd, Crushing Animals, supra note 62, at 237, 253-54. 
of signifier can express the same emotion without the harm done by other types of signifiers? Perhaps one particular signifier within a type of signifiers could do the same?

For example, if a word is considered obscene or offensive by many, can the same emotion expressed by the offensive word be expressed by another word? As we shall see in Section VI(A)(3), one strand of Supreme Court analysis has recognized that not all words are fungible. This same fungibility question applies to icons and indices as well. In the case of icons, could the emotion an artist expressed in an angry but "obscene" painting be equally expressed by another painting or by words that are not obscene? In the case of indices, should a purple weathervane used solely to proclaim wind direction be protected against contrary zoning regulations when a zoning-compliant weathervane would work as well?

\section{Emotion and Reasons for Protecting Freedom of Expression}

To answer such questions, we must of course consider the reasons for protecting freedom of expression and how such reasons might play into any balancing of rights. At least three reasons are commonly given for protecting freedom of expression. First, protecting freedom of speech protects democracy and our right to self-governance since we need the right to express ourselves if we are to truly participate in democracy. ${ }^{161}$ Second, protecting freedom of speech protects the search for truth in an unfettered marketplace of ideas. ${ }^{162}$ Third, and as a catchall, protecting freedom of speech protects autonomy of self, development of self, fulfillment of self, expression of self, and tolerance. ${ }^{163}$

All three of these rationales no doubt promote protection of both pensive and affective emotional expression. To see this, one can return to disgust discussed in Section $V(B)(4)(b)$ above. Again, a general rubric for disgust can read as follows:

161. See id. at 245 .

162. See id.

163. See id. 


\begin{tabular}{|l|l|}
\hline $\begin{array}{l}\text { Prototypical Direct } \\
\text { Object }\end{array}$ & Anyone or anything. \\
\hline Prototypical Appraisal & $\begin{array}{l}\text { The Direct Object as unpleasant or contaminating } \\
\text { (or both) and thus requiring activc rejection. }\end{array}$ \\
\hline Prototypical Narrative & $\begin{array}{l}\text { Life's inclusion of avoidable unpleasantness and } \\
\text { contamination. }\end{array}$ \\
\hline Prototypical Desire & To avoid, rejcet, remove, or disgorge the object. \\
\hline
\end{tabular}

A rubric for a specific case of disgust will depend upon the specific cognitions involved. For example, in the case of a lover of knowledge disgusted at a corrupt and narrow-minded politician he plans to campaign and vote against, the rubric could read as follows:

\begin{tabular}{|l|l|}
\hline Actual Direct Object & The politician. \\
\hline Actual Appraisal & $\begin{array}{l}\text { The politician as corrupt and narrow minded and } \\
\text { thus a possible contaminant of other citizens with } \\
\text { his narrow-minded "agenda." }\end{array}$ \\
\hline Actual Narrative & $\begin{array}{l}\text { Corrupt and narrow-minded politicians misleading } \\
\text { citizens with a narrow-minded "agenda" that } \\
\text { serves the politician's funders. }\end{array}$ \\
\hline Actual Desire & $\begin{array}{l}\text { To express disgust and to remove the contaminant } \\
\text { by voting him out of office. }\end{array}$ \\
\hline
\end{tabular}

There can be no doubt that disgust, at both its prototypical and specific levels, here involves much cognitive expression (apart from the question of whether expression exists in feeling or in other senses as well). ${ }^{164}$ The voter has focuscd on a politician, has evaluated that politician in the context of a broader narrative and factual background, and has a reasoned-out desire to campaign against and vote out that politician. All three reasons for protecting expression come into play here: (1) this involves the marketplace of ideas, (2) this involves our democracy, and (3) this involves self-expression of a person devoted to truth. ${ }^{165}$ Without more, this seems an easy case where we should protect expression of disgust-unless of course countervailing considerations come into the balance. Two common countervailing considerations are fungibility of signifiers and balancing competing rights of parties. ${ }^{166}$ What if the person wishes to use an obscene word to express such disgust? What if the person wishes to use defamatory

164. See supra Section III for example, discussing the role of "feeling" in pursuit of truth.

165. Lloyd, Crushing Animals, supra note 62, at 245

166. See id. at 258. 
words to express such disgust? Should we protect such signifiers where others might be used?

3. Fungibility and Balance

\section{a. Emotion, Expression, and Cohen on Signifiers}

In Cohen v. California, the Supreme Court has unequivocally recognized that:

much linguistic expression serves a dual communicative function: it conveys not only ideas capable of relatively precise, detached explication, but otherwise inexpressible emotions as well. In fact, words are often chosen as much for their emotive as their cognitive force. We cannot sanction the view that the Constitution, while solicitous of the cognitive content of individual speech has little or no regard for that emotive function which practically speaking, may often be the more important element of the overall message sought to be communicated. ${ }^{167}$

In Cohen, the specific phrase "Fuck the Draft" (which uses symbolic signifiers under the terminology used in Section VI(A)(1) above) had emotive expression that the Court found subject to First Amendment protection. ${ }^{168}$ More specifically, in Cohen the Court recognized that other signifiers may not convey the same force as "Fuck the Draft" and thus protected use of that phrase so not to dilute or distort the expression. ${ }^{169}$ On this point, Cohen seems squarely in tune with more modern cognitive theories of emotion. The emotional message of "Fuck the Draft" has meaning that should be protected.

However, on a closer view, Cohen can also be read in a different way. It parses between the "emotive" and the "cognitive" in the phrase "words are often chosen as much for their emotive as their cognitive force."170 Perhaps Cohen underplays the cognitive function of emotion here while still recognizing that we use feeling to engage with the world. ${ }^{171}$ If so, is

167. Cohen v. California, 403 U.S. 15, 26 (1971).

168. Id. at 19-20.

169. Id. at 26 .

170. Id.

171. See supra Section III. 
emotional expression therefore entitled to less protection than nonemotional expression? Perhaps this sort of distinction supports the result we see in Snyder v. Phelps, where verbal expression trumps emotional distress claims. ${ }^{172}$ Perhaps this sort of distinction also supports the way defamation law downplays emotion in the manner discussed in Section VI(A)(3)(b) below. Of course, given the cognitive nature of emotion, we must ask ourselves if such trumping and downplaying of emotion truly makes sense.

\section{b. Snyder, "Truth Value," and Emotions}

\section{As Rebecca Tushnet notes:}

Under modern defamation law, only false factual statements are actionable. That means not just that true statements are protected, but also that nonfalse statements are protected: a claim with no truth value at all cannot be defamatory. This includes statements of pure opinion, unless they imply the existence of particular defamatory factual claims. ${ }^{173}$

Under this approach, emotions will have little if any protection to the extent they are seen as mere feelings that do not make some kind of statement with a truth value. ${ }^{174}$

Consistent with drawing such a line between the "cognitive" and the "emotive," the Supreme Court in Snyder v. Phelps, for example, barred an intentional infliction of emotional distress claim where it found freedom of expression rights trumped any such claim. ${ }^{175}$ In doing so, the Court acted in accordance with its "longstanding refusal to allow damages to be

172. See infra Section $\operatorname{VI}(A)(3)(b)$.

173. Tushnet, supra note 21 , at 2394.

174. Truth values, STANFORD Dictionary OF PHILOSOPHY (Jul. 25, 2016), http://www. http://plato.stanford.edu/entries/truth-values/ (defining as "values indicating the degree of truth of sentences" and "values that are preserved in valid inferences")

175. See Snyder v. Phelps, 562 U.S. 443, 460-61 (2011) ("Speech is powerful. It can stir people to action, move them to tears of both joy and sorrow, and-as it did here - inflict great pain. On the facts before us, we cannot react to that pain by punishing the speaker. As a Nation we have chosen a different course- to protect even hurtful speech on public issues to ensure that we do not stifle public debate. That choice requires that we shield Westboro from tort liability for its picketing in this case."); see also Tushnet, supra note 21, at 2395. 
awarded because the speech in question may have an adverse emotional impact on the audience."176

However, since we have seen that emotions are about specific objects and can thus have truth value, there is no meaningful "truth value" distinction between the "emotive" and the "cognitive" (to use again the words of Cohen). The emotional harms in Phelps for example also involved cognitions and truth values on the part of those injured by the protestors' expression protected by the court. ${ }^{177}$ In suffering emotional injury, those injured no doubt made judgments about themselves, their families, religion, and politics that were inconsistent with those of the protestors' judgments. In addition, doing things out of respect for fallen soldiers itself carries a message. If we design a dignified funeral to honor a fallen soldier, that is an expression of honor and respect for that soldier. The funeral may also be intended to honor country and patriotism. Why should such counter narratives and expression here not merit the same careful review we give those of the protestors whose actions interfere with such other expression?

To answer such questions, we have to balance rights, and we should be honest that expression rights conflict in such cases or we will never find good ways to balance such rights. That of course is not to say that all counter narratives counterweigh the initial narrative. Alan M. Lerner, for example, gives an excellent outline of the counter narratives at play in the flag burning case of Texas $v$. Johnson where anger was, in my view, appropriately trumped by the expression of burning of the flag. ${ }^{178}$ What I am saying, however, is that counter narratives should not be dismissed offhand as "merely emotional." To the extent such emotions are cognitive, they merit full consideration when balancing rights in light of the purposes of the First Amendment and any other applicable law. ${ }^{179}$

\section{c. Unique Indexical Issues}

I will end this brief sampling of freedom of expression issues raised by emotion by noting some interesting questions raised by the potentially

176. Hustler Magazine v. Falwell, 485 U.S. 46, 55 (1988)

177. In Snyder v. Phelps, 562 U.S. 443 (2011), the father of a fallen Marine brought suit against members of the Westboro Baptist Church for emotional distress after the Church picketed his son's funeral, holding signs such as "Thank God for Dead Soldiers," "God Hates Fags," and "You're Going to Hell." Id. at 448.

178. Lerner, supra note 2, at 158-59.

179. See also supra Section $\mathrm{VI}(\mathrm{A})(2)$ regarding the various purposes of the First Amendment. 
involuntary nature of indexical expression. Though we should be able to control our words (symbols) and paint brushes (icons), indexicals can be much less within our control.

For example, we can betray "anger" in our facial expressions. ${ }^{180} \mathrm{We}$ "betray" emotions when we manifest them "in an unmediated or, at most, a minimally intentional way." 181 Perhaps our face involuntarily blushes when we feel anger or hate or disgust. Not only do we know that we can have our own particular physical reactions to emotion, but many psychologists believe, for example, that there is "consistent evidence for pan-cultural facial expressions for five emotions: anger, fear, sadness, enjoyment, and disgust." " 182 There is also evidence for "emotion-specific autonomic nervous system (ANS) activity in the case of anger, fear, disgust and sadness." 183 However one comes down on whether emotions have "pan-cultural" indicators, we no doubt indicate "emotion in voice, face, gesture, and posture" which indication serves "an important function in communicating our emotional state to othcrs." 184

Betrayal of emotions raises interesting and difficult First Amendment questions. First, what do we do when unacceptable emotions are actually betrayed? Do we fire teachers whose facial expressions show disgust for minority children even though they never voluntarily express opinions of disgust? I think we do because a balancing of rights requires something like strict liability in this context. Second, what do we do with bigots who we know may not be able to control betrayed emotion? Do we keep so-far publicly-quiet bigots away from teaching children because they may nonetheless publicly betray their disgust for certain children? Answers to these questions require examination of the reasons for protecting freedom of expression and the need to balance expression rights against the rights of others (including others' emotional counter-expression rights and rights not to be harmed).

180. See SOlOMON, PASSIONS, supra note 70, at 229.

181. See Derek Matravers, Expression in the Arts, in THE OXFORD HANDBOOK OF PHILOSOPHY OF EMOTION, supra note 30, at 540 [hereinafter Matravers, Expression in the Arts]; see also Lloyd, Crushing Animals, supra note 62, at 253-54.

182. Ekman \& Davidson, supra note 25, at $409,413$.

183. Id. at 413 .

184. Robert W. Ievenson, Human Emotion: A Functional View, in THE NATURE OF EMOTION, supra note 25, at 123, 125 [hereinafter Levenson, Human Emotion]. 


\section{The Need for Future Work}

Of course, all this brings us back to the original areas of inquiry: (1) how and what do individuals express through emotion, (2) when does protecting emotional expression (including emotional counter-expression) advance underlying First Amendment rationales, and (3) how do we balance $^{185}$ expression rights against both emotional counter-expression rights and rights not to be harmed? Obviously, much fundamental work remains to be done here.

\section{B. Emotion as Elements and Exceptions in Criminal Law}

A better grasp of affective experience can help us better evaluate legal rules and exceptions to those rules. Though this topic merits volumes in itself, I can only touch on one example here: the common law definition of murder. I choose this example because it illustrates the important distinction between affective and pensive emotions ${ }^{186}$ and because it helps us make sense of something that might seem odd to those first examining the common law definition of murder.

At common law, murder is defined as "[ $t]$ he killing of a human being with malice aforethought." 187 "Malice aforethought" is defined to include any of the following: "(1) the intent to kill, (2) the intent to inflict grievous bodily harm, (3) extremely reckless indifference to the value of human life..., or (4) the intent to commit a felony (which leads to culpability under the felony-murder rule)." 188

A thoughtful law student looking at these definitions for the first time might find them odd. Is malice not something like the emotion of hatred, and should not some element of passion or emotion therefore be involved if we are truly speaking of malice? The thorough student might look up the definition of "malice" thinking it might include some sort of passion or emotion that transfers into the murder definition. Doing so, the student would find that "malice" for legal purposes means either "[t]he intent, without justification or excuse, to commit a wrongful act" or "[r]eckless disregard of the law or of a person's legal rights." 189 The definition she was

185. Lloyd, Crushing Animals, supra note 62, at 244.

186. See supra Section III.D.

187. Murder, Black's Law Dictionary (7th ed. 1999).

188. Malice Aforethought, Black's Law Dictionary (7th ed. 1999).

189. Malice, BLACK'S LAw DictionARY (7th ed. 1999). 
likely looking for ("[i]ll will; wickedness of heart") is noted to apply more to contexts outside the law. ${ }^{190}$

At this point, the students could simply stop further inquiry and just memorize the rule and definitions without further attempt to understand them. This, however, would be a mistake for a couple of reasons. First, it is easier to learn and remember things whose purpose one understands. Second, law students will make better lawyers implementing rules whose purpose they understand. Taking what we have said so far about emotions and affective experience, I believe one can make sense of this puzzle and see that in this case the law has it right.

The student is right to see malice as analogous to hatred. As demonstrated in Section V(B)(4)(a) above, hatred involves a desire to cause another sentient being harm or pain. At least two of the definitions of "malice aforethought" expressly involve the same: "the intent to kill" and "the intent to inflict grievous bodily harm." 191 When we remember that emotions can be "pensive" as well as "affective," the students' quandary should disappear. As shown in Section III(D) above, an emotion becomes "affective" rather than "pensive" when a personal stake becomes involved. Whether a killer has a personal stake in intentionally killing another human being of course should not be a required element of criminalizing the act. ${ }^{192}$ We would consider intentionally killing someone "for the hell of it" no less criminal than intentionally killing someone in a situation involving some personal concern. (We might even consider killing someone "for the hell of it" even worse and a better grasp of how emotions work would help us explore this further should we desire.) Thus, the definition of "malice aforethought" properly requires only pensive malice, not emotional malice, which would require the additional element of a personal stake.

However, the law properly recognizes the role of affective experience in constructing exceptions to the rule. For example, "voluntary manslaughter" is defined as "[a]n act of murder reduced to [the lesser crime of] manslaughter ${ }^{193}$ because of extenuating circumstances such as adequate provocation (arousing the "heat of passion") or diminished capacity."194

190. Id.

191. Malice Aforethought, Black's Law Dictionary (7th ed. 1999).

192. For example, Bandes reminds us that "Judge Posner notes that sometimes the worst crime is the one committed by the defendant who is shockingly devoid of emotion." Bandes, supra note 5, at 4.

193. Manslaughter, BLACK's LAW DiCTIONARY 976 (7th ed. 1999) ("Manslaughter" is "[t]he unlawful killing of a human being without malice aforethought.").

194. Voluntary Manslaughter, BLACK's LAW DICTIONARY (7th ed. 1999). 
"Heat of passion" is defined as "[r]age, terror, or furious hatred suddenly aroused by some immediate provocation, [usually] another person's words or actions." ${ }^{195}$ Here the law recognizes the role of affective experience in what we do and that at times culpability should be mitigated by the effects of such experience. Distinguishing between pensive and affective emotion thus allows one to make sense of both the murder rule (based upon pensive malice) and exceptions to the rule (not restricted to pensive experience).

\section{Emotion and Lawyer Mental Health}

Lawyers have high rates of depression and substance abuse. ${ }^{196}$ Though the reasons for this are no doubt complex, I hope the previous review of ways in which emotion and affective experience work can provide some guidance for lawyer emotional and thus mental health. In the hope of providing further help, I will briefly explore the emotions of guilt, remorse, and regret as they might impact lawyer mental health. I pick these three emotions because lawyers will not always succeed and are thus easy candidates for such emotions. I also pick these three emotions because they illustrate yet again the importance of cognitive precision in emotion.

1. Lawyers and Guilt

In exploring guilt, a general rubric for guilt can read as follows:

195. Heat of Passion, BLACK's Law Dictionary (7th ed. 1999).

196. Frederic S. Ury \& Deborah M. Garskof, Health and Fitness, in EsSENTIAL QUALITIES OF THE PRofessional LAwYer 219, 220 (Paul A. Haskins, ed. 2013) (stating that lawyers "have the highest rate of depression" and that the American Bar Association "estimates that 15 to 20 percent of all lawyers suffer from alcohol or substance abuse") (internal citations omitted). 


\begin{tabular}{|l|l|}
\hline $\begin{array}{l}\text { Prototypical Direct } \\
\text { Object }\end{array}$ & Oneself. \\
\hline Prototypical Appraisal & $\begin{array}{l}\text { "Extreme self-dislike and reproach" of oneself } \\
\text { "in general"198 where one "has violated moral } \\
\text { standards" and deserves "self-administered } \\
\text { punishment."199 }\end{array}$ \\
\hline Prototypical Narrative & $\begin{array}{l}\text { Oneself as an "inadequate and offensive } \\
\text { creature."200 }\end{array}$ \\
\hline Prototypical Desire & $\begin{array}{l}\text { "To punish oneself ... short of self-destruction } \\
\text { (which would eliminate possibility for further } \\
\text { punishment)."201 }\end{array}$ \\
\hline
\end{tabular}

As of course they should, lawyers by virtue of their very craft internalize the importance of many different rules and norms. This means that when lawyers err and violate such rules and norms, they have violated rules and norms that they have embraced. Having embraced such rules and norms, lawyers cannot and should not take such violations lightly. This does not mean, however, that lawyers should engage in the self-flagellation of guilt when no reasonable person would recommend such self-inflicted punishment. As in all other cognitive matters, lawyers should ask themselves if the guilt that they might otherwise "automatically" feel is reasonable. For example, if a lawyer finds a typographical error in a contract she had prepared and carefully reviewed, or if she loses a case despite her best efforts, when would a reasonable person recommend the self-flagellation of guilt?

Frankly, for me at least, it is difficult to see how guilt (as opposed to remorse or regret discussed below) could be an appropriate emotion in either such case. ${ }^{202}$ First, the lawyer in neither case acted with any morallyculpable negligence. With the typo, she made the inevitable mistake that

197. With inner-directed emotions such as guilt, one can easily be confused as to the direct object of the emotion since one will also likely find outer-directed objects of concern as well. For example, if one feels guilty for having frightened a client, one is thinking of at least two other "objects" besides oneself: the client and whatever caused the fear. We might speak of these other two objects as indirect objects of the emotion of guilt whose direct object is the "guilty" person.

198. SOLOMON, PASSIONS, supra note 70, at 259-60.

199. Guilt, THE PENGUIN DICTIONARY OF PSYCHOLOGY (4th ed. 2009).

200. SOLOMON, PASSIONS, supra note 70, at 260-61.

201. Id. at 261 .

202. For the same reasons (except for the first) that I give for recommending against guilt in these two specific cases, I have problems accepting that the self-flagellation of guilt is ever an appropriate emotion. However, I take no position on that here and leave that broader discussion for another time. 
even the most diligent lawyer will eventually make if she practices long enough. Humans are not perfect, and lawyers insure against such an inevitable and unavoidable mistake. With the trial, there is no clear indication that she erred in any way at all. Second, self-flagellation injures and potentially weakens the lawyer. How does that fix anything? Third, self-flagellation takes up time and energy that the lawyer could better use fixing the lawyer's mistakes. Fourth, guilt here leaps from particular error to general condemnation of self. How is one generally bad if one makes one typographical error or if one loses one case? This commits both errors of composition (assuming the whole is like one part) and "hasty generalization" (drawing general inductive conclusions from too little evidence) ${ }^{203}$ Fifth, even if one error made a person a "bad" draftsman or one lost case made a person a bad litigator, that person would be "bad" in the factual sense of how the person drafts or litigates. "Bad" in the sense of factual incompetence does not mean "bad" in the sense of evil, and lawyers of all people should not equivocate upon their terms. ${ }^{204}$ Sixth, as Solomon notes, when we would judge our own guilt we are often a "more ruthless and less reasonable judge than any other [we] could find." ${ }^{205}$ Lawyers should defend fairness and due process for themselves as well as for their clients. Seventh, guilt has no pre-ordained limitations period and can thus go on forever. That means that the self-flagellation may never stop inflicting pain, sapping strength, and distracting the self-flagellator not only from solutions to errors already made but from new accomplishments as well.

It should thus not surprise us when self-flagellating lawyers turn to alcohol or drugs to relieve their potentially endless pain. Mired in a combination of such self-flagellation and such "self-medication," it should also not surprise us when such lawyers descend into the abyss. Fortunately, it does not have to end this way if we understand how emotion works and how it can be refined.

203. See LANHAM, supra note 3, at 51 (fallacy of "composition" is "taking a part for the whole"); BARKER, supra note 4, at 189 (discussing "hasty induction" or "hasty generalization" "when the evidence is too slight to make the conclusion very probable").

204. One could be morally "bad" if one lies about one's drafting abilities or continues to draft knowing one cannot do suitable drafting. Self-flagellation fixes none of this but, again, draws away energy and focus from fixing the problem here whether that fix be a new line of work or seeking additional drafting instruction.

205. SOLOMON, PASSIONS, supra note 70 , at 259 . 


\section{Lawyers and Remorse}

Emotionally-intelligent lawyers should thus explore emotions other than guilt as possibly more suitable where, again, they find a typographical error in a contract that they had prepared and carefully reviewed or where they lose a case despite their best efforts. One such emotion can be remorse. I would set out its rubric as follows:

\begin{tabular}{|l|l|}
\hline $\begin{array}{l}\text { Prototypical Direct } \\
\text { Object }\end{array}$ & Oneself \\
\hline Prototypical Appraisal & $\begin{array}{l}\text { Blaming oneself for an event, act, or omission } \\
\text { which is wrong or undesirable but in either case } \\
\text { pardonable. }\end{array}$ \\
\hline Prototypical Narrative & $\begin{array}{l}\text { Oneself as responsible yet imperfect and thus } \\
\text { subject to pardon or forgiveness if genuinely } \\
\text { sought. }\end{array}$ \\
\hline Prototypical Desire & $\begin{array}{l}\text { Pardon or forgiveness } \\
\text { or omission. }{ }^{208}\end{array}$ \\
\hline
\end{tabular}

Returning to our two examples of lawyer disappointment, remorse is likely a more intelligent emotional response to one of these examples when compared to guilt. In the case of the contract typographical error, remorse would accept responsibility for the error because it was lawyer's work product, and the lawyer made a mistake despite taking great precautions. Rather than wallowing in guilt, however, remorse would move forward to try to make things right. Remorse would both try to fix the problem quickly and to make amends with those aggrieved. An emotionally-intelligent lawyer here would thus have remorse and not guilt. Remorse, however, would not seem suitable for the case a lawyer lost despite best efforts and without any indication of error on the part of the lawyer. To suggest the

206. Solomon distinguishes between "remorse" and "regret," and I find this useful as well. See SOLOMON, PASSIONS, supra note 70, at 287-89. I also find useful his inclusion of pardon in regret but disagree with him to the extent that he might hold that regret must have a desire for self-punishment. See id. at 289. For me, the great insight of remorse over guilt is the insight of the greater value of seeking pardon or forgiveness rather than the brute act of wallowing in self-flagellation.

207. See id. at 289.

208. I have seen no other authors set out the prototypical desire of remorse in this exact way. However, as discussed in Section V(D) above, one can refine emotions to better account for experience. This formulation of remorse is one that I would find very useful when preparing students for the errors they will no doubt make in practice despite their greatest care. Own the mistake but quickly take all steps necessary to make amends and fix the mistake. As I have defined my terms, guilt in such a case would at best be a painful distraction from the needed and more productive remorse. 
lawyer needs forgiveness and pardon in such a case makes no sense because the lawyer did not cause the result.

\section{Lawyers and Regret}

An emotionally-intelligent lawyer would thus seek more appropriate emotions than guilt or remorse for her response after having "lost" such a case. One such emotion can be regret. I would set out its rubric as follows:

\begin{tabular}{|l|l|}
\hline $\begin{array}{l}\text { Prototypical Direct } \\
\text { Object }\end{array}$ & Oneself. \\
\hline Prototypical Appraisal & $\begin{array}{l}\text { One's act or omission as undesirable yet beyond } \\
\text { one's control. }\end{array}$ \\
\hline Prototypical Narrative & Life as determined in whole or in part. \\
\hline Prototypical Desire & Something more desirable than what transpired. ${ }^{209}$ \\
\hline
\end{tabular}

So defined, regret on its face is the better fit for the case lost despite any apparent lawyer error. It does not, however, fit the case of the transactional lawyer's typographical error. Regret does not accept responsibility, and that behavior is not appropriate for a lawyer who made a mistake. Distinguishing remorse and regret is thus not mere pedantry. It provides guidance for good and healthy practice of law.

\section{CONCLUSION}

Emotion is cognitive, and law is inextricably intertwined with both emotion and reason. As we work on reforming legal education, we must acknowledge this fact and recognize and explore affective experience in legal education and in practice. If we fail to do this, we shortchange law schools, students, and the bar in grievous ways.

First, we shortchange the very basics of true and best legal analysis. Not only is affect part of reason, but affect can actually refine reason and analysis in multiple ways. Affective experience gives us additional insight into the world as demonstrated by the Huck Finn and Lieutenant Commander Michael Riley examples discussed in Section III(A) above.

209. One could reasonably debate whether, like remorse, this should also include a desire to "fix" what happened. I do not include this in regret because here the result was not the direct object's responsibility who has no necessarily-immediate moral imperative to act. Ilowever, as emotions should be constantly refined, I look forward to hearing others' opinions now that I have raised the question in this way. 
Furthermore, in Richard Shweder's words, "affective experience is an invitation to wonder why, to ask what those feelings reveal, to investigate various orders of reality (biochemical, interpersonal, moral), to diagnose one's biochemical, interpersonal, and moral standing in the world, and to make plans accordingly." 210 As Lemer also notes, "combining conscious consideration of one's emotion and intuition with careful legal analysis can contribute to achieving a more fully informed, and therefore better reasoned and more appropriate decision."211

Second, we shortchange at least half the universe of expression. Emotional expression is no less intentional than "rational" expression, and those who would understand and protect expression cannot reasonably ignore it. Honestly acknowledging this additional universe of intentional expression also involves acknowledging difficult problems of balancing conflicting expression rights. However, the uncharted territories here should intrigue us rather than daunt us, and we should explore them with enthusiasm.

Third, we shortchange the importance of "watch[ing] the individual's interests." 212 As discussed above, the affective is defined in terms of personal stake or concern. ${ }^{213}$ How can a lawyer represent his client well if he does not know his client's real interests, real interests which by definition involve affective considerations?

Fourth, we shortchange the importance of motivation in law and life. ${ }^{214}$ How can lawyers understand the motives of clients and other relevant parties without understanding the emotions that motivate them? Additionally, how can lawyers hope to persuade judges, other advocates, or parties across the table in a transaction without at least some grasp of the elements of the emotions appropriate for such motivation (in addition of course to the emotions otherwise motivating such parties)? $?^{215}$

210. Shweder, You're Not Sick, supra note 66, at 32, 42.

211. Lerner, supra note 2, at 161.

212. Nico Frijda, Emotions are Functional, Most of the Time, in WHAT IS AN EMOTION? CLASSIC AND CONTEMPORARY READINGS, supra note 12, at 136 [hereinafter Frijda, Emotions are Functional].

213. See supra Section III(D).

214. See Motivation, The Penguin Dictionary of Psychology (4th ed. 2009) ("[E]motional states tend to have motivational properties.").

215. Furthermore, good law professors want to know how to motivate students to learn. Part of this can be as simple as understanding that emotions motivate us "to the extent to which people seek to maximize the experience of positive emotions and to minimize the experience of negative emotions." 
Finally, we shortchange matters of life and death. ${ }^{216}$ As Ekman and Davidson note, "One's emotional experience affects one's well-being and may have implications for one's physical health." ${ }^{17}$ To the extent that law and the "rational life" are reduced to emotionless reflection, we lose all affective experience, including preference. Without preference we have indifference, and indifference is hard to distinguish from "anhedonia," or "a general lack of interest in the pleasures of life." 218 That is hardly a recipe for health or healthy counsel.

Ekman \& Davidson, supra note 25 , at $\mathbf{4 1 2}$. An unpleasant classroom is unlikely to motivate learning despite any protestations of a Professor Kingsfield to the contrary.

216. $I d$.

217. Id.

218. Depression, The Pengun Dictionary of PSychology (4th ed. 2009). 
APPENDIX:

RUBRICS OF SEVERAL SPECIFIC EMOTIONS

Anger

\begin{tabular}{|l|l|}
\hline $\begin{array}{l}\text { Prototypical Direct } \\
\text { Object }\end{array}$ & $\begin{array}{l}\text { Anyone or anything perceived as an agent } \\
\text { subject to moral judgment. }\end{array}$ \\
\hline Prototypical Appraisal & $\begin{array}{l}\text { The Direct Object as culpably causing an } \\
\text { "unjust harm" to someone or something. }\end{array}$ \\
\hline Prototypical Narrative & Judging and punishing wrongdoers. ${ }^{220}$ \\
\hline Prototypical Desire & "To punish" the Direct Object. ${ }^{21}$ \\
\hline
\end{tabular}

Contempt

\begin{tabular}{|l|l|}
\hline $\begin{array}{l}\text { Prototypical Direct } \\
\text { Object }\end{array}$ & Anyone or anything. \\
\hline Prototypical Appraisal & $\begin{array}{l}\text { "Severe" appraisal222 of the Direct Object as } \\
\text { "inferior" or "unworthy."223 }\end{array}$ \\
\hline Prototypical Narrative & $\begin{array}{l}\text { One as superior to the Direct Object and thus } \\
\text { rightly avoiding or ostracizing it. }\end{array}$ \\
\hline Prototypical Desire & To "ostracize or avoid" the Direct Object.225 \\
\hline
\end{tabular}

Disgust

\begin{tabular}{|l|l|}
\hline $\begin{array}{l}\text { Prototypical Direct } \\
\text { Object }\end{array}$ & Anyone or anything. \\
\hline Prototypical Appraisal & $\begin{array}{l}\text { The Direct Object as unpleasant or } \\
\text { contaminating (or both) and thus requiring } \\
\text { active rejection. }\end{array}$ \\
\hline Prototypical Narrative & $\begin{array}{l}\text { Situations with unpleasantness or contamination } \\
\text { or both. }\end{array}$ \\
\hline Prototypical Desire & $\begin{array}{l}\text { To avoid, reject, remove, or disgorge the Direct } \\
\text { Object. }\end{array}$ \\
\hline
\end{tabular}

219. See Elster, Emotional Choice, supra note 30, at 268.

220. See SOLOMON, PASSIONS supra note 70, at 229.

221. Id. Anger can often be identified by a "collection of physical reactions, ... [such as] facial grimaces and body positions...." See Anger, THE PENGUIN DiCTIONARY of PsYChology (4th ed 2009). Anger can be a "fairly strong emotional reaction" that "hedges into other emotional reactions of similar kind such as animus, rage, hostility, hatred." Id. Because of anger's strength and desire to punish, an emotionally-intelligent person takes care not to confuse mere frustration with anger.

222. See SOLOMON, PASSIONS, supra note 70 , at 234

223. See Contempt, THE PENGUIN Dictionary of PSYChOlOGy (4th ed. 2009).

224. See SOLOMON, PASSIONS, supra note 70, at 233-34 (metaphors often used with contempt include the Direct Object as "a snake, a reptile, an insect, a worm, a spider" or "as slime or excrement, as degenerate or depraved").

225. See Elster, Emotional Choice, supra note 30, at 271 
Embarrassment

\begin{tabular}{|l|l|}
\hline $\begin{array}{l}\text { Prototypical Direct } \\
\text { Object }\end{array}$ & Oneself. \\
\hline Prototypical Appraisal & $\begin{array}{l}\text { Something negative about or relating to the } \\
\text { Direct Object but not due to the fault of the } \\
\text { Direct Object. }\end{array}$ \\
\hline Prototypical Narrative & $\begin{array}{l}\text { Fate or others making sport of the Direct } \\
\text { Object. }\end{array}$ \\
\hline Prototypical Desire & "To hide."228 \\
\hline
\end{tabular}

Envy

\begin{tabular}{|l|l|}
\hline $\begin{array}{l}\text { Prototypical Direct } \\
\text { Object }\end{array}$ & Anyone or anything. ${ }^{229}$ \\
\hline Prototypical Appraisal & $\begin{array}{l}\text { The Direct Object having something highly } \\
\text { valued. }^{230}\end{array}$ \\
\hline Prototypical Narrative & Situations (or life) as unfair or wanting. $^{\text {Poto }}$ \\
\hline Prototypical Desire & $\begin{array}{l}\text { To have or take (with or without malice) what } \\
\text { the Direct Object has. }^{231}\end{array}$ \\
\hline
\end{tabular}

226. See SOLOMON, PASSIONS, supra note 70, at 246 (one can be embarrassed for another only to the extent one identifies with that other).

227. See id. at 247 (One might be embarrassed about a tear in one's pants that one did not cause or notice before one appears in public. Shame, on the other hand, requires an element of fault as discussed in the rubric below.)

228. Id. at 247.

229. I see no reason why, for example, we cannot envy a bird's ability to fly or the moon's ability to wax after it wanes.

230. See id.

231. See Richard Lazarus, Universal Antecedents of the Emotions, in THE NATURE OF EMOTION: FUNDAMENTAL QUESTIONS, supra note 25, at 163-64 [hereinafter Lazarus, Universal Antecedents]; Richard S. \& Bernice N. Lazarus, PASSION \& REASON: MAKING SENSE OF OUR EMOTIONS 32 (1994) [hereinafter PASSION \& REASON] ("[E]nvy can be benign in the sense that we may admire another and wish that person no harm" but "it can also be malicious and cruel."). 
Fear

\begin{tabular}{|l|l|}
\hline $\begin{array}{l}\text { Prototypical Direct } \\
\text { Object }\end{array}$ & Anyone or anything. \\
\hline Prototypical Appraisal & The Direct Object as "dangerous or noxious."232 \\
\hline Prototypical Narrative & $\begin{array}{l}\text { Situations as dangerous or highly unpleasant or } \\
\text { both. }\end{array}$ \\
\hline Prototypical Desire & "[T]o avoid or escape" the Dircct Object. ${ }^{233}$ \\
\hline
\end{tabular}

\section{Frustration}

\begin{tabular}{|l|l|}
\hline $\begin{array}{l}\text { Prototypical Direct } \\
\text { Object }\end{array}$ & Anyone or anything. \\
\hline Prototypical Appraisal & $\begin{array}{l}\text { The Direct Object as desired but blocked, } \\
\text { interfered with, or disrupted. }{ }^{234}\end{array}$ \\
\hline Prototypical Narrative & $\begin{array}{l}\text { Situations (or life) as unpredictable or difficult } \\
\text { or both. }\end{array}$ \\
\hline Prototypical Desire & To have the Direct Object. \\
\hline
\end{tabular}

\section{Grief}

\begin{tabular}{|l|l|}
\hline $\begin{array}{l}\text { Prototypical Direct } \\
\text { Object }\end{array}$ & $\begin{array}{l}\text { Anyone or anything with which one had a deep } \\
\text { "bond."235 }\end{array}$ \\
\hline Prototypical Appraisal & Loss of the Direct Object and all that entails. \\
\hline Prototypical Narrative & $\begin{array}{l}\text { "The mythology of mourning, 'I have lost a part } \\
\text { of myself.",237 }\end{array}$ \\
\hline Prototypical Desire & "To regain what is lost."238 \\
\hline
\end{tabular}

232. Fear, The PEnguin Dictionary OF PSyciology (4th cd. 2009).

233. See SOlOMON, PASSIONS, supra note 70 , at 255 ; see also Fear, THE PENGUIN DictionaRY OF PSYCHOLOGY (4th ed. 2009) (Fear is "usually characterized by an internal, subjective experience of extreme agitation, a desire to flee or attack, and a variety of sympathetic reactions.").

234. See Frustration, THE PENGUIN DiCTIONARY OF PSYCHOLOGY (4th ed. 2009). Unlike anger, there is not necessarily a moral component (though there can be) in the forces acting against us. One should thus take care not to confound mere innocent frustration with anger over unjust harm. No doubt much unnecessary pain and suffering results from such confusion both in the emotional person and those around him.

235. Grief, The Penguin Dictionary of Psychology 307 (4th ed. 2009).

236. See id.

237. SOLOMON, PASSIONS, supra note 70, at 298.

238. Id. 
Guilt

\begin{tabular}{|l|l|}
\hline $\begin{array}{l}\text { Prototypical Direct } \\
\text { Object }\end{array}$ & Oneself. \\
\hline Prototypical Appraisal & $\begin{array}{l}\text { "Extreme self-dislike and reproach" of oneself } \\
\text { "in general"240 where one "has violated moral } \\
\text { standards" and deserves "self-administered } \\
\text { punishment."241 }\end{array}$ \\
\hline Prototypical Narrative & $\begin{array}{l}\text { Oneself as an "inadequate and offensive } \\
\text { creature."242 }\end{array}$ \\
\hline Prototypical Desire & $\begin{array}{l}\text { "To punish oneself ... short of self-destruction } \\
\text { (which would eliminate possibility for further } \\
\text { punishment)."243 }\end{array}$ \\
\hline
\end{tabular}

\section{Hatred}

\begin{tabular}{|l|l|}
\hline $\begin{array}{l}\text { Prototypical Direct } \\
\text { Object }^{244}\end{array}$ & Anyone or anything perceived as sentient. \\
\hline Prototypical Appraisal & $\begin{array}{l}\text { The Direct Object as evil and thus deserving } \\
\text { pain or other harm. }\end{array}$ \\
\hline Prototypical Narrative & "[A] battle between good and evil."245 \\
\hline Prototypical Desire & $\begin{array}{l}\text { To cause pain or other harm to the Direct Object } \\
\text { and to have a sense of righteousness in doing } \\
\text { so. }\end{array}$ \\
\hline
\end{tabular}

239. Again, with inner-directed emotions such as guilt, one can easily be confused as to the direct object of the emotion, since one will also likely find outer-directed objects of concern as well. For example, if one feels guilty for having frightened a client, one is thinking of at least two other "objects" besides oneself: the client and whatever caused the fear. We might speak of these other two objects as indirect objects of the emotion of guilt whose direct object is the "guilty" person.

240. Id. at 259-60.

241. Guilt, THE PENGUIN DictionaRy OF PSychology 310 (4th ed. 2009).

242. SOLOMON, PASSIONS, supra note 70, at 260-61.

243. Id. at 261.

244. See supra Sections III(B) and VI(C)(1) where I distinguish between possible direct and indirect objects of emotion. In the interest of space, I do not attempt to lay out any such indirect objects of the various emotions.

245. SOLOMON, PASSIONS, supra note 70, at 266; see also Elster, Emotional Choice, supra note 30 , at 268 (hatred based on belief that the person hated is "evil"). 
Jealousy

\begin{tabular}{|l|l|}
\hline $\begin{array}{l}\text { Prototypical Direct } \\
\text { Object }\end{array}$ & Anyone or anything. \\
\hline Prototypical Appraisal & $\begin{array}{l}\text { The Direct Object as a rival for or a "threat to } \\
\text { another's affection or favor."246 }\end{array}$ \\
\hline Prototypical Narrative & Affection and favor as "zero-sum" games. ${ }^{247}$ \\
\hline Prototypical Desire & $\begin{array}{l}\text { Maintaining or restoring a monopoly on such } \\
\text { affection or favor. }\end{array}$ \\
\hline
\end{tabular}

Malice

\begin{tabular}{|l|l|}
\hline $\begin{array}{l}\text { Prototypical Direct } \\
\text { Object }\end{array}$ & Anyone or anything perceived as sentient. \\
\hline Prototypical Appraisal & $\begin{array}{l}\text { The Direct Object as a suitable target of pain or } \\
\text { other harm. }{ }^{248}\end{array}$ \\
\hline Prototypical Narrative & $\begin{array}{l}\text { The world as including sentient things suitably } \\
\text { targeted for pain or other harm. }\end{array}$ \\
\hline Prototypical Desire & $\begin{array}{l}\text { To cause pain or other harm to the Direct } \\
\text { Object. }^{249}\end{array}$ \\
\hline
\end{tabular}

246. Lazarus, Universal Antecedents, supra note 231, at 163-64; see also Jealousy, THE PENGUIN Dictionary OF PSYCHOLOGY (4th ed. 2009) (jealousy is "directed toward a third party, the rival"). The loved or favored one would thus be an indirect object of the jealousy rather than the direct object. Jealousy is distinguished from envy "where there need be no loved one, merely a desire for things possessed by the rival." $I d$. at 406 .

247. See PASSION \& REASON, supra note 231 , at 38.

248. Unlike hatred, pure malice does not appraise the direct object as evil. In fact, one can have malice for those one knows nothing about. For example, one might wish a flat tire for the unknown driver of a car with a political sticker one finds objectionable. Even worse, a pathological killer might wish to kill an unknown victim just because the victim happens to be in a place making the victim a feasible target of such a crime.

249. In my view, emotions like envy require us to distinguish between anger and hatred on the one hand (which both involve some sort of perceived moral problem with the Direct Object) and malice on the other (which does not require such a perceived moral problem with the Direct Object). The maliciously-envied person, for example, may have done nothing wrong in acquiring the thing envied. This "emotional" definition of "malice" can be compared with the legal definition set forth in Section VI(B) above. 
Pity

\begin{tabular}{|l|l|}
\hline $\begin{array}{l}\text { Prototypical Direct } \\
\text { Object }\end{array}$ & Anyone or anything perceived as sentient. \\
\hline Prototypical Appraisal & $\begin{array}{l}\text { The Direct Object has suffered undeserved } \\
\text { "misfortune, loss, injury"250 or "distress."251 }\end{array}$ \\
\hline Prototypical Narrative & "There but for the grace of God go I."252 \\
\hline Prototypical Desire & To console or heal the Direct Object. ${ }^{253}$ \\
\hline
\end{tabular}

Pride

\begin{tabular}{|l|l|}
\hline $\begin{array}{l}\text { Prototypical Direct } \\
\text { Object }\end{array}$ & $\begin{array}{l}\text { Oneself or anyone or anything with which one } \\
\text { identifies. }\end{array}$ \\
\hline Prototypical Appraisal & $\begin{array}{l}\text { The Direct Object deserves credit for "efforts } \\
\text { made and gains accomplished."255 }\end{array}$ \\
\hline Prototypical Narrative & $\begin{array}{l}\text { Agents can improve themselves and do other } \\
\text { good things if they put forth the effort. }\end{array}$ \\
\hline Prototypical Desire & $\begin{array}{l}\text { Recognition of the Dircct Object's "efforts made } \\
\text { and gains accomplished."256 }\end{array}$ \\
\hline
\end{tabular}

Regret

\begin{tabular}{|l|l|}
\hline $\begin{array}{l}\text { Prototypical Direct } \\
\text { Object }\end{array}$ & Oneself. \\
\hline Prototypical Appraisal & $\begin{array}{l}\text { One's act or omission as undesirable yet beyond } \\
\text { one's control. }\end{array}$ \\
\hline Prototypical Narrative & Life as determined in whole or in part. \\
\hline Prototypical Desire & $\begin{array}{l}\text { Something more desirable than what } \\
\text { transpired. }\end{array}$ \\
\hline
\end{tabular}

250. See SOLOMON, PASSIONS, supra note 70, at 282.

251. See Elster, Emotional Choice, supra note 30, at 268.

252. See SOLOMON, PASSIONS, supra note 70 , at 283 . Improper pity can see the Direct Object as demeaned and thus rendered inferior by the misfortune and can even be used as an excuse to make the pitying party feel superior. See id. at 281-84.

253. See Elster, Emotional Choice, supra note 30, at 268; see also Solomon, PASsIons, supra note 70 , at 283 .

254. See Lazarus, Universal Antecedents, supra note 231, at 164.

255. See Pride, The Penguin Dictionary of Psychology (4th ed. 2009).

256. Id: SOLOMON, PASSIONS, supra note 70, at 286. Despite its bad name, pride can be a worthy emotion advancing "personal dignity and self-esteem" unless it is "false pride," i.e., "a bloated fantasy of self-esteem too flimsily tied to a foundation of insignificant accomplishment, used more as a weapon ... [for] superiority than as a straightforward appeal for dignity." Id. at 284-85. Thus gay people rightly have a gay pride month to foster dignity and self-esteem based on real history and accomplishments.

257. Again, one could reasonably debate whether, like remorse, this should also include a desire to "fix" what happened. I would not include this in regret because here the result was not the direct object's responsibility; thus, the direct object has no necessarily-immediate moral imperative to act. 
Remorse

\begin{tabular}{|l|l|}
\hline $\begin{array}{l}\text { Prototypical Direct } \\
\text { Object }\end{array}$ & Oneself. \\
\hline Prototypical Appraisal & $\begin{array}{l}\text { Blaming oneself for an event, act, or omission } \\
\text { which is wrong or undesirable but in either case } \\
\text { pardonable. }\end{array}$ \\
\hline Prototypical Narrative & $\begin{array}{l}\text { Oneself as responsible yet imperfect and thus } \\
\text { subject to pardon or forgiveness if genuinely } \\
\text { sought. }\end{array}$ \\
\hline Prototypical Desire & $\begin{array}{l}\text { Pardon or forgiveness } \\
\text { or }{ }^{259} \text { plus remedying the act } \\
\text { oro }\end{array}$ \\
\hline
\end{tabular}

\section{Resentment}

\begin{tabular}{|l|l|}
\hline $\begin{array}{l}\text { Prototypical Direct } \\
\text { Object }\end{array}$ & Anyone or anything. \\
\hline Prototypical Appraisal & $\begin{array}{l}\text { The Direct Object has either received unfair } \\
\text { advantage or has caused one to suffer unfair } \\
\text { disadvantage. }\end{array}$ \\
\hline Prototypical Narrative & Life as unfair and often a "zero-sum" game. ${ }^{261}$ \\
\hline Prototypical Desire & Punishing or harming the Direct Object. \\
\hline
\end{tabular}

However, as emotions should be constantly refined, I would enjoy hearing what others think now that I have raised the question in this way.

258. Again, Solomon distinguishes between "remorse" and "regret," and I find this useful as well. See SOLOMON, PASSIONS, supra note 70, at 287-89. I also find useful his inclusion of pardon in regret but disagree with him to the extent he might hold regret must have a desire for self-punishment. See id. at 289. For me, the great insight of remorse over guilt is the insight of the greater value of seeking pardon or forgiveness rather than the brute act of wallowing in self-flagellation.

259. See id. at 289 .

260. Again, I have seen no others set out the prototypical desire of remorse in this exact way. However, as discussed supra Section V(D), emotions can always be refined to better account for experience. This formulation of remorse is one I would find very useful when preparing students for the errors they will no doubt make in practice despite their greatest care. Own the mistake but quickly take all steps necessary to make amends and fix the mistake. As I have defined my terms, guilt in such a case would at best be a painful distraction from the needed and more productive remorse.

261. Much resentment could disappear if we realized that life is not a "zero-sum" game. For example, one sibling resenting the "unfair" share of a parent's attention on another sibling might well lose that resentment upon recognizing that attention is potentially limitless. Instead of wallowing in resentment, she could instead work to get her "fair" share of that potentially limitless attention. 
Shame

\begin{tabular}{|l|l|}
\hline $\begin{array}{l}\text { Prototypical Direct } \\
\text { Object }\end{array}$ & Oneself \\
\hline Prototypical Appraisal & $\begin{array}{l}\text { One "has acted dishonourably or } \\
\text { ridiculously"262 or has otherwise failed to meet } \\
\text { ideals one accepts. }\end{array}$ \\
\hline Prototypical Narrative & $\begin{array}{l}\text { Judging and righting or punishing wrong or } \\
\text { failure. }^{264}\end{array}$ \\
\hline Prototypical Desire & $\begin{array}{l}\text { "To atone and expiate"265 and often to hide or } \\
\text { flee. }\end{array}$ \\
\hline
\end{tabular}

These rubrics read in light of the Article preceding them are offered as starting points for encouraging and developing greater emotional intelligence in lawyers, judges, law students, and in the practice and discipline of law itself. By "emotional intelligence," I am comfortable with the following as a working definition: the "[a]bility to monitor one's own and other people's emotions, to discriminate between different emotions and label them appropriately, and to use emotional informational information to guide thinking and behaviour." 267

262. Shame, The Penguin Dictionary of Psychology (4th ed. 2009)

263. See PASSION \& REASON, supra note 231, at 41.

264. See SOLOMON, PASSIONS, supra note 70, at 301-02.

265. Id. at 302 .

266. See Elster, Emotional Choice, supra note 30, at 271. In extreme cases, one might wish to kill oneself. See id.

267. Emotional Intelligence, OXFORD DICTIONARY OF PSYCHOLOGY (3d ed. 2009). 